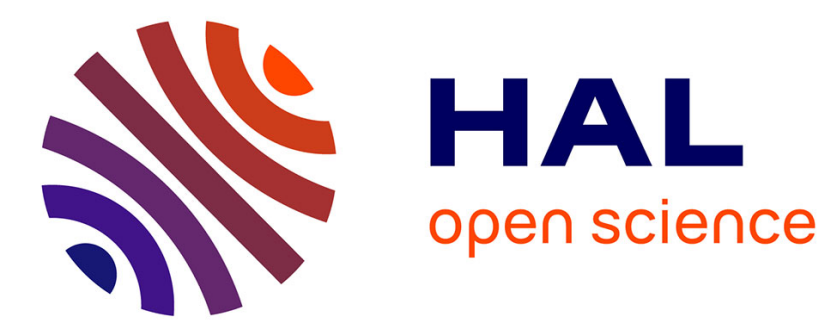

\title{
Economic, pro-social and pro-environmental factors influencing participation in an incentive-based conservation program in Bolivia
}

Manon Authelet, Julie Subervie, Patrick Meyfroidt, Niguel Asquith, Driss Ezzine-de Blas

\section{To cite this version:}

Manon Authelet, Julie Subervie, Patrick Meyfroidt, Niguel Asquith, Driss Ezzine-de Blas. Economic, pro-social and pro-environmental factors influencing participation in an incentive-based conservation program in Bolivia. 2020. hal-02513101

\section{HAL Id: hal-02513101 \\ https://hal.umontpellier.fr/hal-02513101}

Preprint submitted on 20 Mar 2020

HAL is a multi-disciplinary open access archive for the deposit and dissemination of scientific research documents, whether they are published or not. The documents may come from teaching and research institutions in France or abroad, or from public or private research centers.
L'archive ouverte pluridisciplinaire HAL, est destinée au dépôt et à la diffusion de documents scientifiques de niveau recherche, publiés ou non, émanant des établissements d'enseignement et de recherche français ou étrangers, des laboratoires publics ou privés. 


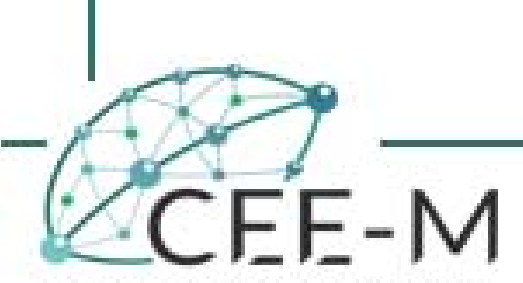

Economic, Pro-social and Pro-environmental Factors Influencing Participation in an Incentive-based Conservation Program in Bolivia

\author{
Manon Authelet, \\ Julie Subervie, \\ Patrick Meyfroidt, \\ Nigel Asquith \\ $\&$
}

Driss Ezzine-de-Blas

CEE-M Working Paper 2020-03 
Economic, Pro-social and Pro-environmental Factors Influencing Participation in an

Incentive-based Conservation Program in Bolivia

Manon Authelet ${ }^{1}$, Julie Subervie $^{2}$, Patrick Meyfroidt $^{3}$, Nigel Asquith $^{4,5}$, Driss Ezzine-de-Blas $^{6}$

${ }^{1}$ Corresponding author - Gembloux Agro-Bio Tech, University of Liege (ULg), Belgium - manon.authelet@gmail.com 10 Rue du Paquis, 6760 Gomery - +32/497.14.62.05

${ }^{2}$ Center for Environmental Economics of Montpellier (CEE-M), French National Institute for Agricultural Research (INRA), France - julie.subervie@inra.fr

${ }^{3}$ Earth and Life Institute (ELI), Catholic University of Louvain (UCL), Belgium - patrick.meyfroidt@uclouvain.be ${ }^{4}$ Cuencas Sustentables, Bolivia - nigelasquith@yahoo.com

${ }^{5}$ Harvard Forest and Sustainability Science Program, Kennedy School of Government (KSG), Harvard University, United States of America

${ }^{6}$ Internal Research Unit on Forests and Societies (UPR F\&S), French Agricultural Research Centre for International Development (CIRAD), France - ezzine@ cirad.fr

\begin{abstract}
The effectiveness of incentive-based conservation programs depends on how they influence and interact with multiple motivations of the participants. Here, we studied an incentive-based program for forest conservation in Bolivia - called "Reciprocal Water Agreements" - that mixes material compensations with pro-social and pro-environmental motivations as a way to reduce crowding-out of intrinsic motivations and to increase participation. Based on a sample of 424 households who were offered the program, we analysed econometrically the households' characteristics that influenced (i) the probability of participation in the program, (ii) the intensity of the participation, measured as the area allocated in the agreement, and (iii) the modality of participation, measured as the probability of participation in the different types of agreements. We found that economic factors favoured participation of better-off households owning property titles, more forested land with lower conservation opportunity cost, more agricultural tools and access to off-farm income. In addition, both pro-social factors - a deeper or older integration into social networks, and greater compliance to social norms of reciprocity, but also weaker institutional trust - as well as pro-environmental factors - including awareness of environmental problems, greater knowledge about solutions to environmental problems and a perceived positive balance of gains and losses in ecosystem services - also influenced positively the probability of participation and the area involved in the program. Finally, we found that participation into more restrictive agreements was enabled by a stronger sense of individual responsibility towards environmental problems and a weaker perceived control over environmental behaviours. Our results highlight the factors that could increase uptake and factors on which the program might focus in order to have a greater impact on pro-environmental behaviours. They also suggest that incentive-based program can be designed to take advantage of pro-social and pro-environmental motivations as strongly as of economic ones.
\end{abstract}

\title{
Keywords
}

Motivations; participation; incentive-based conservation program; forest conservation; South America; Bolivia. 


\section{Introduction}

Payments for Environmental Services (PES) ${ }^{1}$ have been widely advocated as an efficient and effective socio-economic and institutional instrument to preserve and improve the provision of ecosystem services (Engel \& Palmer, 2008; Wunder et al., 2008) and have been widely implemented around the world, including in tropical forest regions (Ezzine-de-Blas et al., 2016; Grima et al., 2016).

One key but insufficiently explored critique of PES is that relying on extrinsic, often monetary, motivations for the targeted behaviour may undermine intrinsic motivations, potentially jeopardizing the long-term effectiveness of the intervention. Social psychology describes this as "motivation crowding", in which external incentives can either lead to the reinforcement ("crowding-in") of intrinsic motivations, or their replacement (“crowding-out") by extrinsic motivations (Moros et al., 2019; Benabou \& Tirole, 2003; Bowles \& Polonia-Reyes, 2012; Rode et al., 2015; Neuteleers \& Engelen, 2015; Frey \& Oberholzer-Gee, 1997). Intrinsic motivations correspond to the inherent satisfaction that the activity brings, resulting from a combined set of psychological moderators including autonomy, personal development and a sense of social and environmental belonging. Extrinsic motivations correspond to the instrumental value derived from the activity, i.e. the motivation to perform an activity to achieve a separable result that can be material, monetary or non-material benefits, such as social recognition (Ryan \& Deci, 2000; Ezzine-de-Blas et al., 2019).

Anticipating the risks of ineffectiveness or inefficiency that can derive from the crowding out of intrinsic motivations requires further exploring the links between incentive-based conservation and pre-existing and post-intervention motivations and behaviours (Vatn, 2010; Muradian et al., 2010; Moros et al., 2019; Levine et al., 2015; Rode et al., 2015; Ezzine-de-Blas et al., 2019). Embracing the multidimensionality of the motivations and barriers influencing participation into PES is also key to identify which ones can be used to improve the uptake of the program.

Studies analysing the factors affecting participation in PES schemes have highlighted the importance of economic factors (such as the size of farm, access to alternative source of incomes, and ownership of land title) and access to information or knowledge, which represent barriers to entry, affecting the ability and eligibility to participate and transaction and opportunity costs (Bremer et al., 2014; Pagiola et al., 2005). Participants in Costa Rica's national PSA program were characterized by on average more land-intensive and larger farms and farm incomes, were better educated, had more income from and were proportionately more reliant on off-farm incomes - which probably increased their management skills - and 
had also greater access to information about the program (Zbinden \& Lee 2005). Similarly, in Ecuador's SocioPáramo program, land tenure requirements, legal or biophysical land-use restrictions, and a need for pre-existing social, human, and financial capital facilitated the in-take of larger and wealthier landowners, having access to alternative livelihood incomes and lower opportunity cost related to the program land-use restrictions (Bremer et al., 2014). Using a contingent valuation methodology, Seroa da Mottaa \& Arigoni Ortiz (2018) found that opportunity costs, inertia to changes in production modes, fear of additional monitoring, and level of understanding of the program influenced farmers' decision to join a PES program in the Paraíba do Sul River basin in Brazil. Several studies showed that pro-environmental factors had a positive effect on participation, such as the value placed on ecosystem services (Bremer et al., 2014; Bottazzi et al., 2018; García-Amado et al., 2013; Hayes, 2012), environmental knowledge or awareness (Seroa da Mottaa \& Arigoni Ortiz, 2018) or moral values (Van Hecken \& Bastianensen, 2010). A few studies have investigated the role of pro-social factors in triggering participation. Bremer et al., (2014) found a positive influence of social capital in the form of social networks with institutions and of community organization, which facilitated awareness of the program and completion of entry requirements for community and smallholder participants in Ecuador's SocioPáramo PES program. Grillos (2017) found that social embeddedness, including participation in community work and in the communal decision-making institution, and time of residence in community, increased participation in a Bolivian in-kind incentive-based program. Chen (2012) found that social norms, through social interactions before decision-making, increased re-enrollment of land in a Chinese PES program. On the contrary, in Bottazzi et al., (2018), pro-social motivations were the least cited reasons cited by participants and did not have a significant effect on the decision to participate.

In this article, we study an in-kind incentive-based conservation program in Bolivia whose strategy is to build on pro-social and pro-environmental motivations to foster participation, in particular through social embeddedness and instrumental value of water-related ecosystem services, in addition to classic economic incentives (Grillos, 2017 and Bottazzi et al., 2018).

We make three contributions to the current literature. First, we propose a theoretical framework that builds on the combination of three perspectives on environmental decision-making or behaviour, namely utility maximization, collective action, and environmentally responsible behaviour, to identify the economic, pro-social and pro-environmental factors that explain participation in the program. Second, using econometric models and controlling for conventional economic factors, we quantify the separate impact of these three types of factors on the decision to participate but also on the size of the land that participants decide to enroll. Third, we study how heterogeneity in the agreement - in terms of the importance of the 
land for water services, conservation commitments and amount of compensation - interact with households' characteristics to explain participation in the most restrictive and rewarding agreement type. We use data from a comprehensive preintervention survey of 424 households in order to estimate econometric models explaining (i) the probability of participation in the program, (ii) the intensity of participation, measured as the area allocated in the agreement, and (iii) the modality of participation, measured as the probability of participation in the different types of agreements.

Our analysis shows that all three groups of factors contain variables that significantly influence the probability and intensity of participation, with a stronger influence of economic and pro-social characteristics, while pro-environmental factors influence more strongly the participation to more restrictive agreements. In particular, we find that richer households, with property titles, more forested land, more agricultural tools and access to off-farm incomes were more likely to sign an ARA and commit a large part of their farm to the program, presumably because they faced less entry barriers. In addition, both pro-social factors - related to a deeper or older integration into social networks, greater compliance to social norms of reciprocity, but also a weaker institutional trust - as well as pro-environmental factors - including the awareness of environmental problems, greater knowledge about solutions and a perceived positive balance of gains and losses in ecosystem services - also influenced positively the probability of participation and the area of land involved in the program. Finally, a stronger individual responsibility towards environmental problems and a weaker perceived control over environmental behaviour increased the participation into more restrictive agreements.

The paper is organized as follows: Section 2 presents our theoretical framework based for analysing determinants of households' participation in PES based on theories of environmental decision-making. Section 3 presents the content and the specificities of the program under study. Section 4 provides the materials and methods. Section 5 presents the results, which are discussed in Section 6.

\section{Theoretical foundations to understand participation in incentive-based conservation}

Three main streams of literature can help to understand the decision made by rural households to voluntarily participate in an in-kind incentive-based conservation program. First, classic economic theory describes a rational agent which makes decisions in order to maximise utility. Second, theories of collective actions problems describes environmental management decisions as situations in which altruistic individuals may renounce to individual benefits in the short term in order to generate long-term societal benefits. Third, social and environmental psychology describes pro-environmental or 
conservation-friendly behaviours using psycho-social factors related to values, attitudes, beliefs, norms, needs and knowledge, among many others.

In classic economic theory, conditional economic incentives are conceptualised assuming that conservation decisions are made by balancing economic reward from the participation to the program and opportunity costs - foregone income due to restrictions if participating to the program -, and to maximize the economic utility of the households' productive activities, according to their assets, labour force, availability of land and sources of income, among other factors. De Janvry \& Sadoulet (2006) have modelled rural household behaviour under market failure conditions, which are frequent in developing countries and correspond to the conditions of our study area. They present a conceptual framework that makes it possible to model the behaviour of rural households - as agricultural productive units - in the form of maximizing a series of utilities.

In contrast, building on the collective action literature, participation in incentive-based conservation can also be framed as a contribution to collective action and environmental stewardship, as part of an altruistic or socially responsible behaviour (Crilly, Schneider \& Zollo, 2008). In this theoretical approach, environmental problems are rooted in problems of collective action, i.e. a situation of social dilemma where everyone has to participate to the conservation of a common good and sacrifice individual benefits to generate a societal or common benefit. Under social dilemma, each isolated individual lacks sufficient incentives or capacity to act alone, while collective action building on pro-social behaviours has the potential to address the problem (Ostrom et al., 1998). Under this perspective, participation in incentive-based conservation can be considered as a case of collective action where households decide to cooperate and commit themselves to the protection of their environment for the benefit of their community, downstream communities or society at large, while an economic incentive can help to reduce this individual cost-benefit dilemma (Muradian, 2013). This social dimension of environmental behaviours is particularly relevant in rural Bolivia, where households, living in communities, have intertwined social interactions (Section 3). Ostrom's collective action theory shows that trust (individuals' expectations about others' behaviours), reciprocity (norms that individuals learn from socialization and life experiences) and reputation (identities that individuals create and that project their intentions and norms), which are causally linked, are conditions that support collective action. These social phenomena are driving forces of cooperation, which in turn determines the net benefits generated by the use of the common resource for a given group (Ostrom, 1998). Social capital, defined as "the attributes of individuals and of their relationships that strengthen their ability to solve collective action problems" (Ostrom \& Ahn, 2009) or "the norms and networks within a civil society that invoke cooperative behaviours in various governance actors" 
(Putnam's, 1994) also plays a key role in environmental policy issues and for understanding collective action for the environment (e.g., Pretty \& Ward, 2001; Pretty, 2003; Selman, 2001; Jones et al., 2009a, 2009b, 2011). Social capital is generally articulated in four components: social trust, institutional trust, compliance with social norms ${ }^{2}$ and participation in social networks (Bourdieu, 1986; Woolcock \& Narayan, 2000; Bowles \& Gintis, 2002; Jones, 2010; Jin, 2013).

Thirdly, since participants in incentive-based conservation commit to protect part of their environment, their decision can also be characterized as "environmentally responsible behaviours", also called "pro-environmental behaviours", theorized in social and environmental psychology as individual behaviours that are consciously carried out to have a positive impact on the environment and its protection (Stern, 2000). Bamberg \& Möser (2007) proposes a framework that identifies a number of psycho-social variables that are consistently associated with pro-environmental behaviour, regardless of the political, social and economic context. They show that pro-environmental behaviour is mainly mediated by the intention to act pro-environmentally, which itself is influenced more or less equally by three other factors: attitudes (the perceived positive and negative personal consequences that would result from choosing this pro-environmental option compared to other options), perceived behavioural control (the perceived difficulty to perform the pro-environmental option compared to other options) and moral norms (the perceived reasons indicating a moral obligation for performing the pro-environmental option). These three factors are strongly influenced by four other interacting psycho-social constructs: problem awareness and internal attribution (cognitive factors), feelings of guilt (emotional factors) and social norms (social factors) (Bamberg \& Möser, 2007).

Other works have explored ways to integrate these different perspectives. Ezzine-de-Blas et al., (2019) drew on the SelfDetermination Theory (Ryan \& Deci, 2000) and others to propose an additional relevant conceptual framework for understanding the motivations to participate into an incentive-based conservation program. It describes how external incentives' design and features could increase or decrease intrinsic motivations versus extrinsic motivations and consequently improve the performance of the desired conservation behaviour (either participation in the program, or the efficiency of the targeted behaviour and the compliance to the program), by supporting moderators of psycho-social needs and well-being: competence through recognition of skills and personal development, autonomy through inclusive design, social relatedness through reciprocity, distributive and procedural equity and group or community inclusion and environmental relatedness through feeling of belonging, well-being and awareness of healthy environment. 


\section{An in-kind incentive-based forest and water conservation program in Bolivia}

Forests have an extremely important role to play regarding climate change adaptation/mitigation and the local and global regulation of water flows and temperature (Ellison et al., 2017). In particular, Andean natural ecosystems and cloud montane forests are very important for local and regional water services provision (Célleri and Feyen, 2009, Bonnesoeur et al., 2019). These ecosystems also provide other services, such as controlling water erosion and floods and stabilizing soils against landslides in steep terrain (Bathurst et al., 2010; Guns \& Vanacker, 2013). However, deforestation related to livestock grazing and conversion to pastures among other causes, increases erosion and landslides risks by reducing slope stability (Guns \& Vanacker, 2013). For example, in the high Andes of Ecuador, converting natural forests to agricultural lands has led to high loss of the capacity of the landscape to deliver many ecosystem services, including on-site protection against water erosion and off-site water yield provision and erosion regulation (Balthazar et al., 2015). From 2001 to 2017 , Bolivia lost 7\% of its tree cover, representing 4.53 Mha and $374 \mathrm{Mt}$ of $\mathrm{CO}_{2}$ emissions (Global Forest Watch, 2018).

To mitigate these problems, Natura Foundation Bolivia (hereinafter referred to as "Natura"), a local NGO, has been implementing an incentive-based conservation program for 15 years in Bolivia. Their program is offered through agreements, called Reciprocal Water Agreements, or "Watershared" Agreements ("Acuerdos Recíprocos por el Agua", hereafter referred to as "ARA"), to upstream rural farming households (water service providers), whose land use practices influence the provision of water services for downstream urban dwellers (water service users). Through these agreements, upstream farmers agree to conserve part of their forests and their water sources in order to provide clean and sufficient water to downstream users, in exchange for material compensations. These compensations are paid by 1) the downstream municipal government - drawing from the redistribution of the national budget linked to the decentralisation of environmental management responsibilities, 2) the public water service cooperative operating in the municipality - by adding an additional percentage onto members' monthly water bills, and 3) Natura - from international donors and private organisations. Together, these contributors comprise a newly created institution, a "Local Water Fund". ARAs aim to avoid some of the previously described pitfalls of traditional PES programs. Aligning with recommendations from the recent literature (Wunder, 2006; Farley \& Costanza, 2010; Cranford \& Mourato, 2011; García-Amado et al., 2013), this program builds on economic motivations through direct in-kind compensations as well as on other supportive and intrinsic motivations, with the expressed aim of reducing the risk of crowding-out and the cost of the program (Asquith et al., 2016) 
Firstly, ARAs use in-kind compensations proportional to the area put into conservation to support farmers to improve their local production systems, to reduce their detrimental impacts on forest and water resources. These compensations include equipment relative to irrigation (pipes, water pumps, etc.), fruticulture (fruit trees, fertilizers, etc.), beekeeping (hives, beekeeper suit, gloves, etc.) and improved livestock management (barbed wire, water troughs, fodder seeds, etc.). Some of these in-kind compensations are also meant to improve household living conditions (e.g. water pipe, roof sheets, and water tanks). In order to minimize the impact of economic incentives on intrinsic motivations and to give room for other types of motivations, the monetary value of material compensations is not calculated according to the opportunity cost of households. These compensations are thus low and not intended to motivate potential participants by maximizing their utility. Rather, these materials are intended to materialize a form of social recognition (see next paragraph).

Secondly, ARAs also rely on social norms in several ways. Technicians present ARAs to communities as a form of ancestral reciprocal work ("Ayni") towards the mother earth. "Ayni” is a traditional unpaid exchange of agricultural work that takes place individually between two people or households and that still exists in some Bolivian communities. Other forms of ancestral reciprocal work in the region are "Minga" and "Faena" which consist respectively in regular collective work for community infrastructure and in rotational collective work where several families come together to help another one for an activity that requires a large workforce. The principle of reciprocity is specifically referred to in the program name, "Reciprocal Water Agreements". Other ways in which the program mobilises social norms is through social marketing, such as by using reputation as a motivation to participate. By publicly distributing the compensations and framing them as rewards to the households that have signed and respected their agreements in front of members of their communities, and sometimes of other communities ${ }^{4}$, implementors highlight the social importance of households that contribute to the protection of forest and water sources and to the well-being of their communities and downstream households. Moreover, the fact that downstream users contribute to the funding of the compensations through their water bills, also intends to show to upstream communities that downstream users value and recognize the environmental services they provide in order to encourage them (point often repeated by technicians when offering ARAs to communities). The distribution of the compensations is often organized in places of high social significance - e. g. the municipality square or at very popular agricultural fairs. These rewards are given directly and individually to each household, accompanied with a diploma and a photograph, with the aim of creating both a sense of personal commitment and of social pride and reputation. 
Finally, the entire program is designed to build on pro-environmental motivations. When ARA is offered to communities, it is prefaced by an environmental education session ${ }^{5}$ discussing the water cycle, i.e., how forest cover influences soil protection, structure and retention, and in turn water infiltration and purification of water, runoff and erosion, and how evapotranspiration from vegetation influences rainfall. As landslides, floods, as well as droughts, are common and increasingly frequent phenomena in the region, this information is expected to be a motivation for participation. The program also uses a productivist and utilitarian discourse, publicly calling forests "water factories", to discuss the link between forests and water quantity and quality. ARAs and forest protection are presented as an effective way to ensure clean and abundant water supply not only for downstream households but also for communities themselves.

In this study, we focus on a set of ARA agreements that were implemented in 2015, for three years, in two municipalities in the Bolivian Chaco, Monteagudo and Villa Vaca Guzman (Figure 1). Each household could engage different parts of their forests in three different types of agreements, with different levels of compensation depending on the importance of the forest for water services and assumed conservation commitments (Table 1). The provisions common to all three types of agreements were the prohibition of land-use change (no cultivation, no slash-and-burn, and no road opening), of cutting trees for commercial purposes, of plant and humus extraction, and of hunting within the enrolled area. However, of these, only the interdictions on land-use change and tree cutting were monitored. Type 1 and 2 agreements were established in riparian forests, located at a maximum of 100 meters from a water source or stream. Type 1 agreements required households to exclude livestock from the agreement area, so that the livestock did not contaminate the water, whereas in Type 2 , household only engaged to reduce the entry of livestock, but without penalty if livestock was observed in the agreement area. Type 3 agreements could apply to all types of forested land. Type 1 agreements had the greatest potential additionality, as they required actual changes in management to exclude cows from riparian forests, which often necessitated the installation of barbed wire. Type 1 agreements entitled households to receive $\$ 100$ upon signing and material compensations for a value of $10 \$ /$ ha/year for three years, while Type 2 and Type 3 agreements corresponded to material compensations equivalent to $5 \$ /$ ha/year and $3 \$ /$ ha/year, respectively. To enter into an agreement, a household needed to meet certain requirements, i.e. own forested land de jure (with a property title) or de facto (through a document from the communal authority acknowledging traditional ownership of the land for a certain number of years), and, for Type 1 and 2 agreements, have a water source or stream surrounded by forest on its property. 


\begin{tabular}{|c|c|c|c|}
\hline Type & 1 & 2 & 3 \\
\hline Type of land & $\begin{array}{l}\text { Riparian forest within max } \\
100 \text { meters of a stream or } \\
\text { water source }\end{array}$ & $\begin{array}{l}\text { Riparian forest within max } \\
100 \text { meters of a stream or } \\
\text { water source }\end{array}$ & $\begin{array}{l}\text { Primary and secondary } \\
\text { forest or shrub land }\end{array}$ \\
\hline Commitments & $\begin{array}{l}\text { - No land-use change (no } \\
\text { cultivation, no slash-and- } \\
\text { burn, no road opening) } \\
\text { - No cutting of trees for } \\
\text { commercial exploitation } \\
\text { (it is permitted to cut for } \\
\text { personal use) } \\
\text { - Livestock prohibited }\end{array}$ & $\begin{array}{l}\text { - No land-use change (no } \\
\text { cultivation, no slash-and- } \\
\text { burn, no road opening) } \\
\text { - No cutting of trees for } \\
\text { commercial exploitation } \\
\text { (it is permitted to cut for } \\
\text { personal use) } \\
\text { - Landowners commit to } \\
\text { gradually reducing } \\
\text { livestock numbers }\end{array}$ & $\begin{array}{l}\text { - No land-use change (no } \\
\text { cultivation, no slash-and- } \\
\text { burn, no road opening) } \\
\text { - No cutting of trees for } \\
\text { commercial exploitation } \\
\text { (it is permitted to cut for } \\
\text { personal use) }\end{array}$ \\
\hline $\begin{array}{l}\text { Value of } \\
\text { compensation }\end{array}$ & $\begin{array}{l}100 \$ \text { at the time of signing } \\
+ \text { in-kind compensation } \\
\text { equivalent to } 10 \$ / \mathrm{ha} / \mathrm{an}\end{array}$ & $\begin{array}{l}\text { In-kind compensation } \\
\text { equivalent to } 5 \$ / \mathrm{h} / \mathrm{an}\end{array}$ & $\begin{array}{l}\text { In-kind compensation } \\
\text { equivalent to } 3 \$ / \mathrm{ha} / \mathrm{an}\end{array}$ \\
\hline
\end{tabular}

Yearly monitoring of presence of cattle, timber extraction or forest clearance in parcels under Type 1 or Type 2 ARA is supposed to confirm compliance (Asquith, 2016; Fundación Natura Bolivia, 2017). Type 3 agreements are monitored remotely, with only points that are suspected of deforestation being visited in the field. In cases of incompliance, the compensation packages received by the household - or their equivalent value - must be returned back to its community. 


\section{Materials and Methods}

\section{Study area}
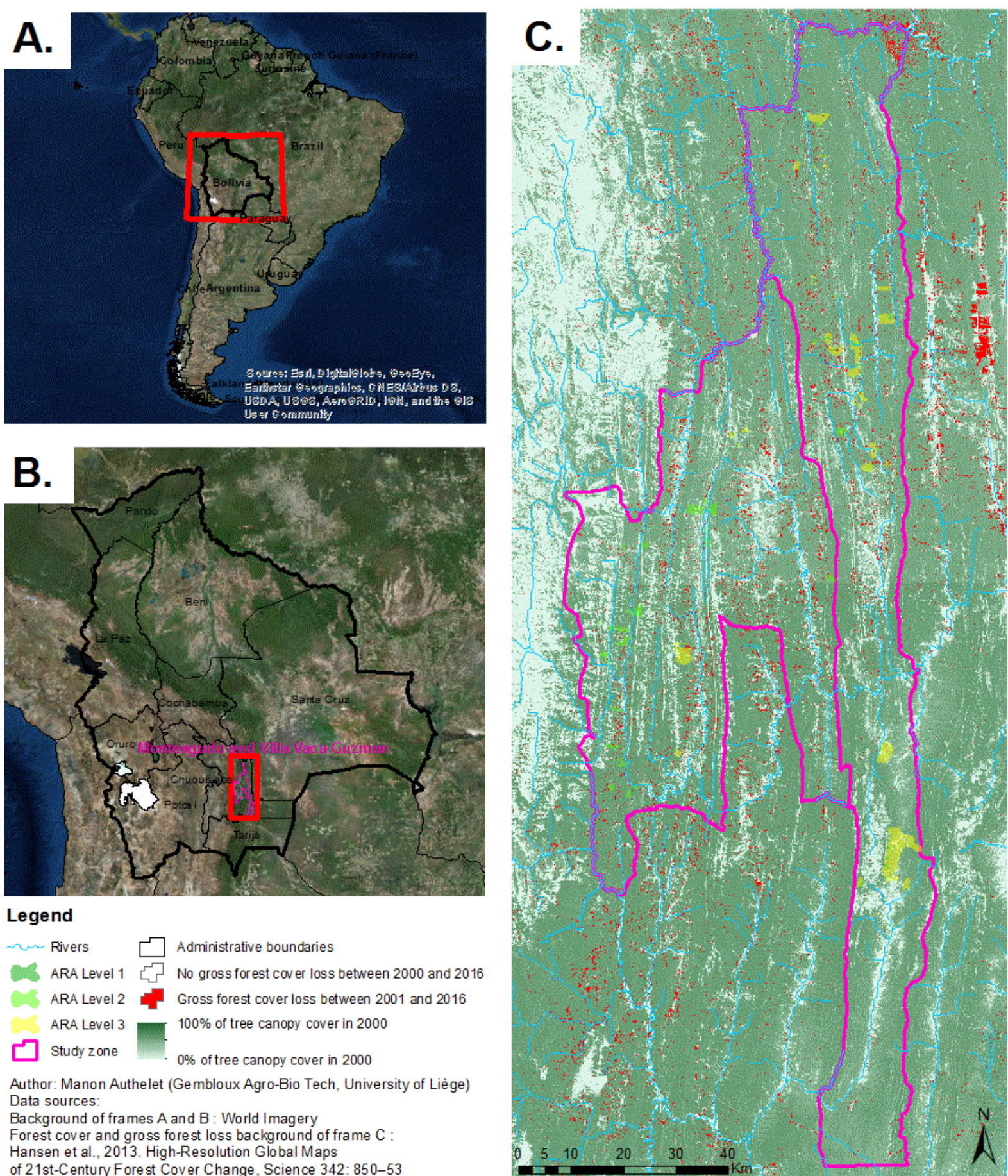

Legend

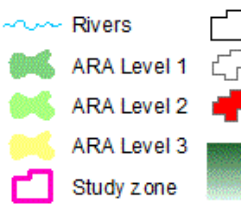

Administrative boundaries

No gross for est cover loss between 2000 and 2016

Gross forest cover loss between 2001 and 2016

$100 \%$ of tree canopy cover in 2000

$0 \%$ of tree canopy cover in 2000

Author: Manon Authelet (Gembloux Agro-Bio Tech, University of Liège) Data sources:

Background of frames A and B: World Imagery

Forest cover and gross forest loss background of frame $C$

Hansen et al., 2013. High-Resolution Global Maps

of 21st-Century Fore st Cover Change, Science 342: 850-53

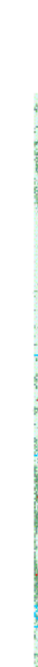


The study area (Figure 1) is located in the transition zone of the inter-Andean valleys, between the Altiplano in the east and the Chaco plains in the west, within the Tucumano-Boliviano Bosque and Chaco Serrano ecoregions (Ibisch et al., 2003). Geomorphologically, it is composed of a series of incised and parallel valleys, extending from north to south, with altitudes varying between approximately 1000 meters for valleys and 1700 meters for peaks. The climate is characterized by a mild and dry season from May to October and a hot and rainy season from November to April.

Farmers cultivate in the humid flat valley bottoms, rich in sediment and silt. Most of the slopes are steep with shallow or rocky soils, unfavourable for agriculture, and are mainly occupied by forest, sometimes degraded by extensive livestock grazing. Some forest patches are being progressively deforested due to the extension of agriculture and grassland pastures for semi-intensive livestock farming.

Farmers live in small communities, legally represented by a Basic Territorial Organisation (Organización Territorial de Base - OTB). These OTBs constitute a key rural institution with their own authority and "executive board", composed of several members who are elected each year by community vote. Members meet monthly to organize community work related to the maintenance and creation of common projects and infrastructure, resolve potential conflicts, and define communal land repartition and forest clearing authorizations, as land tenure systems are characterized by a mix of private and collective land. Traditionally, free grazing in the collective area was allowed, as well as clearing the forest for creating new fields in areas accepted by the OTB. Through several episodes of agrarian reforms $(1952,1996,2006)$, some households acquired private property land titles for the land they used to cultivate under customary tenure. In 2014, in the same community some households could hold a private property while others - generally poorer or latecomers - did not have private property and rent land from private owners or were requesting permission to clear some of the communal land to cultivate. Households with private lands had sometimes transformed part of it into permanent grassland for livestock while conserving access to the communal area in free access for all community members' livestock.

\section{Survey data and sample}

This study uses a comprehensive face-to-face household survey that was conducted by Natura in 22 communities of the municipalities of Monteagudo and Villa Vaca Guzman in Southern Bolivia, as a baseline before initiating the program. In each community, an average of 21 households was surveyed in 2014, one year before Natura offered to each household of these communities to participate in the ARA program. The survey included three set of questions. First, questions related to economic variables such as household demographics, assets, activities, land-use, expenses and income; second, questions 
related to their perception of the institutional, social and environmental context; third, questions aimed at capturing their social and environmental values and motivations.

Households were composed on average by four members. They practiced a combination of sedentary slash-and-burn subsistence with cash crop agriculture, with little or no mechanization, mainly growing corn, groundnuts, beans, peppers and potatoes. Households had on average 47.4 ha $( \pm 6.6)$ of forest, 2.9 ha $( \pm 0.5)$ of grassland, 4.1 ha $( \pm 0.3)$ of crops. They grow on average 3.2 ha $( \pm 0.2)$ of maize, 0.4 ha $( \pm 0.1)$ of groundnuts, 0.3 ha $( \pm 0.1)$ of beans, 0.1 ha $( \pm 0.02)$ of peppers and 0.02 ha $( \pm 0.01)$ of potatoes. Only $3.2 \%$ had a tractor and $22.8 \%$ a plough. They also had an average of 16 cows $( \pm 2), 9$ pigs $( \pm 1)$, and 26 hens $( \pm 6)$.

The study area covers 727,500 ha, from which 27,500 ha were enrolled in conservation, through 293 individual ARAs signed by 178 households (each household can sign several agreements on different plots) (Figure 1). Due to spelling inaccuracies and to the incompleteness of the baseline survey, only 79 from the 178 households in the list of contractholders could be matched with households in the baseline survey, representing a total enrolled area of 15, 000 ha (Frame C of Figure 1). Households in the baseline survey that were not part of the list of contract-holders were designated as nonsignatories. Our dataset thus includes 79 households who signed an ARA and 391 households who did not.

\section{Selection of variables}

We selected a number of variables that are referred to in De Janvry \& Sadoulet (2006) rational choice model, Ostrom's (1998) collective action theory, Jin's (2013) social capital elements, Bamberg \& Moser (2007) environmentally-responsible behaviour model and Ezzine-de-Blas et al., (2019) expanded self-determination theory under external incentives. We created composite variables by aggregating variables with similar meanings - e.g., we grouped the variables of participation in the three types of traditional collective work into a single variable and we grouped the perceptions of forest ecosystem services into provisioning, regulating and cultural services. In order to avoid collinearity, we conducted bivariate association tests for each pair of variables to discard pro-social and pro-environmental variables that were highly correlated with each other or with economic variables. We only kept one variable for each pair of variables with significant ( $\mathrm{p}$-value $<0.05)$ and strong associations (correlation, eta or Cramer's V > 0.30).

Table 2 displays the selected variables, their coding or unit, their theoretical relevance and expected effect on participation0. Economic variables include age and education of the head of the household, variables linked to productive capital such as 
agricultural tools, labour force, animals, available land, land use distribution and ownership and variables linked to other sources of income or liquidity. Pro-social factors that could promote collective action for the environment or that could increase intrinsic motivation through social relatedness include variables related to integration into social networks and the community, social norms of reciprocity and cooperation, social and institutional trust, altruistic or egalitarian versus liberal moral norms. Pro-environmental factors that could promote pro-environmental behaviours or increase intrinsic motivations through environmental relatedness, autonomy or competence include variables related to perceived benefit or loss generated by conservation, environmental social or moral norms, perceived responsibility towards environmental problems, awareness of environmental problem, knowledge of behavioural options and perceived behavioural control or sense of competence related to environmental issues.

Table 2. Variables' meaning, unit, theoretical significance within our framework and expected sense of their effect on participation in incentive-based conservation. The table does not include some variables that were initially selected for their theoretical relevance but were not used in the models as they did not improve models' performance.

\begin{tabular}{|c|c|c|c|}
\hline & Variable meaning (and unit/coding) & Link with theoretical concept & $\begin{array}{l}\text { Expected } \\
\text { effect }\end{array}$ \\
\hline \multirow{18}{*}{ 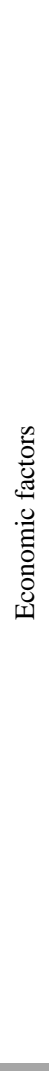 } & Number of members (number) & Labour force & + \\
\hline & Age of the head of the household (years) & Human capital & \pm \\
\hline & Head of the household went to primary school $(1=\mathrm{Yes}, 0=\mathrm{No})$ & Human capital & + \\
\hline & Head of the household went to secondary school $(1=$ Yes, $0=$ No $)$ & Human capital & + \\
\hline & Total land area (ha) & Land capital & + \\
\hline & Proportion of forested land ( $\%$ of land area) & Land capital + Anticipated size of incentives & + \\
\hline & Proportion of grassland (\% of land area) & Land capital & - \\
\hline & Superficies of forested land (ha) & Land capital & + \\
\hline & Superficies of grassland (ha) & Land capital & + \\
\hline & Superficies of cultivated land (ha) & Land capital & + \\
\hline & Owns forested land $(1=$ Yes, $0=\mathrm{No})$ & Land capital + Requisite for entry & + \\
\hline & $\begin{array}{l}\text { Maintained forested land because it was unsuitable for other purposes } \\
(1=\text { Yes, } 0=\mathrm{No})\end{array}$ & Land capital + Requisite for entry + Opportunity cost & + \\
\hline & Owns cultivated land $(1=$ Yes, $0=$ No) & Land capital & + \\
\hline & Number of cows (number) & Assets - Animals & \pm \\
\hline & Owns at least one plough $(1=$ Yes, $0=\mathrm{No})$ & Assets - Tools & + \\
\hline & Owns at least one tractor $(1=$ Yes, $0=\mathrm{No})$ & Assets - Tools & + \\
\hline & $\begin{array}{l}\text { Has a credit with a bank, or a credit union, or a government fund }(1=\text { Yes, } \\
0=\text { No) }\end{array}$ & Source of income & + \\
\hline & Has no other income-generating activities $(1=\mathrm{Yes}, 0=\mathrm{No})$ & Source of income & - \\
\hline \multirow{3}{*}{ 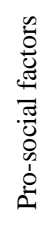 } & Is an authority/was an authority/is a member of an OTB ( $1=$ Yes, $0=$ No) & $\begin{array}{l}\text { Integration into social networks - Social } \\
\text { relatedness/involvement }\end{array}$ & + \\
\hline & Frequency of OTB meetings (number of meetings) & $\begin{array}{l}\text { Integration into social networks - Social relatedness } \\
\text { /involvement }\end{array}$ & + \\
\hline & $\begin{array}{l}\text { Is an authority/was an authority/is a member of a breeders' association } \\
(1=\text { Yes, } 0=\mathrm{No})\end{array}$ & $\begin{array}{l}\text { Integration into social networks - Social relatedness } \\
\text { /involvement }\end{array}$ & + \\
\hline
\end{tabular}




\begin{tabular}{|c|c|c|c|}
\hline & $\begin{array}{l}\text { His an authority/was an authority/is a member of a water cooperative } \\
(1=\text { Yes, } 0=\text { No) }\end{array}$ & $\begin{array}{l}\text { Integration into social networks - Social relatedness } \\
\text { /involvement }\end{array}$ & + \\
\hline & Participates in collective work (Minga, Faena, Ayni) $(1=$ Yes, $0=N o)$ & $\begin{array}{l}\text { Compliance with social norms of reciprocity - Social } \\
\text { relatedness }\end{array}$ & + \\
\hline & $\begin{array}{l}\text { Number of days of community work devoted to water management } \\
\text { (number) }\end{array}$ & $\begin{array}{l}\text { Compliance with social norms of reciprocity - Social } \\
\text { relatedness }\end{array}$ & + \\
\hline & Lives in the community since their generation $(1=\mathrm{Yes}, 0=\mathrm{No})$ & $\begin{array}{l}\text { Integration into social networks - Social and environmental } \\
\text { relatedness }\end{array}$ & + \\
\hline & Lives in the community since the generation of their parents $(1=\mathrm{Yes}, 0=\mathrm{No})$ & $\begin{array}{l}\text { Integration into social networks - Social and environmental } \\
\text { relatedness }\end{array}$ & + \\
\hline & $\begin{array}{l}\text { Lives in the community since the generation of their grandparents }(1=\mathrm{Yes} \text {, } \\
0=\mathrm{No})\end{array}$ & $\begin{array}{l}\text { Integration into social networks - Social and environmental } \\
\text { relatedness }\end{array}$ & + \\
\hline & Trusts institutions and NGOs $(1=\mathrm{Yes}, 0=\mathrm{No})$ & Institutional trust - Social relatedness & + \\
\hline & $\begin{array}{l}\text { Agrees that "People in his community work together to solve common } \\
\text { problems" }(1=\text { Yes, } 0=\text { No })\end{array}$ & Social norms of cooperation - Social trust - Social relatedness & + \\
\hline & Thinks that decisions made by his-her community are fair $(1=\mathrm{Yes}, 0=\mathrm{No})$ & Social trust - Social relatedness & + \\
\hline \multirow{10}{*}{ 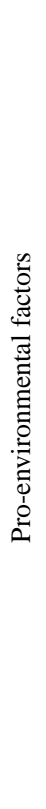 } & $\begin{array}{l}\text { Agrees that "to improve living conditions, it is necessary to damage the } \\
\text { environment." }(1=\text { Yes, } 0=\mathrm{No})\end{array}$ & $\begin{array}{l}\text { Perceived behavioural control - Competence - Perceived loss } \\
\text { from conservation decreasing attitudes }\end{array}$ & - \\
\hline & $\begin{array}{l}\text { Agrees that "if his-her neighbours do nothing for the environment, he-she } \\
\text { should do nothing either." ( } 1=\text { Yes, } 0=\text { No) }\end{array}$ & Individual responsibility & - \\
\hline & $\begin{array}{l}\text { Is in favour of the imposition of forest standards by the government } \\
(1=\text { Yes, } 0=\mathrm{No})\end{array}$ & Problem awareness & + \\
\hline & $\begin{array}{l}\text { Has ideas about what his-her community can do to protect the environment } \\
(1=\text { Yes, } 0=\text { No })\end{array}$ & Knowledge of behavioural options - Competence & + \\
\hline & $\begin{array}{l}\text { Thinks that the forest provides fodder, non-timber forest products, timber, } \\
\text { firewood and bush meat }(1=\text { Yes, } 0=\text { No) }\end{array}$ & $\begin{array}{l}\text { Perceived loss in ecosystem services from conservation } \\
\text { decreasing attitudes- Environmental relatedness }\end{array}$ & \pm \\
\hline & $\begin{array}{l}\text { Thinks that the forest brings rain, maintains water quality, maintains water } \\
\text { quantity, stabilizes the climate }(1=\mathrm{Yes}, 0=\mathrm{No})\end{array}$ & $\begin{array}{l}\text { Perceived benefit in ecosystem services from conservation } \\
\text { increasing attitudes - Environmental relatedness }\end{array}$ & + \\
\hline & Thinks that the forest brings a nice view $(1=$ Yes, $0=\mathrm{No})$ & $\begin{array}{l}\text { Perceived benefit in ecosystem services from conservation } \\
\text { increasing attitudes - Environmental relatedness }\end{array}$ & + \\
\hline & $\begin{array}{l}\text { Environmental protection is an important value that he wants to teach his- } \\
\text { her children }(1=\text { Yes, } 0=\mathrm{No})\end{array}$ & Pro-environmental moral norm & + \\
\hline & Wants support for water and/or environmental management $(1=\mathrm{Yes}, 0=\mathrm{No})$ & Problem awareness - Priorities & + \\
\hline & $\begin{array}{l}\text { Thinks that the destruction of the environment is a major challenge for his- } \\
\text { her community }(1=\text { Yes, } 0=\mathrm{No})\end{array}$ & Problem awareness & + \\
\hline
\end{tabular}

\section{Econometric models}

We estimated three econometric models to assess the effect of the variables mentioned above on i) the likelihood to participate in the program, ii) the intensity of participation in the program, and iii) the likelihood to opt for the most stringent contract. In each case, we first built a standard economic model (De Janvry and Sadoulet, 2006) that we gradually enriched with pro-social and pro-environmental variables to determine the best-fit complete model, including all economic determinants and the set of most significant and robust pro-social and pro-environmental determinants. We moreover controlled for community-specific effects, using dummy variables. Using the economic variables as control variables 
allowed verifying that the added pro-social and pro-environmental variables explained additional part of the variance unexplained by the economic variables.

We first studied the determinants of participation in the program by estimating a maximum-likelihood logit model, where the probability for a farmer to sign an ARA is (Equation 1):

$$
\text { (1) } \operatorname{Pr}(P=1)=F\left(\beta_{0}+\beta_{1} x_{1}+\beta_{2} x_{2}+\cdots+\beta_{n} x_{n}\right)=F\left(\beta_{0}+\beta X\right)
$$

where $F(z)=\frac{e^{z}}{1+e^{z}}$ is the cumulative logistic distribution. The dependent variable $P$ is a dummy that takes the value of one if the household participated in an ARA (whatever the type of ARA chosen) and zero elsewhere. $\beta_{0}$ is a constant term, $X=$ $\left(x_{1}, x_{2}, \ldots, x_{n}\right)$ is the vector of economic, pro-social and pro-environmental covariates for a household and $\beta=$ $\left(\beta_{1}, \beta_{2}, \ldots, \beta_{n}\right)$ is the related vector of coefficients.

We then looked at participation intensity, measured as the surface $S$ enrolled into an ARA. We estimated a Tobit model where the dependent variable $S$ is the number of hectares enrolled in the program and $S^{*}$ is a latent variable. We use Tobit, a special case of censored-normal regression, because $\mathrm{S}$ is censored at zero (Equation 2):

$$
\text { (2) } S=\left\{\begin{array}{l}
S^{*} \text { if } S^{*}>0 \\
0 \text { if } S^{*} \leq 0
\end{array} \text { and } S^{*}=\beta X\right.
$$

Finally, we estimated a multinomial logit model to study the determinants of households' decision to participate in the most stringent type of agreements. We created an unordered categorical variable $H$, that can take three values:

$$
\begin{aligned}
& \text { (3) } \operatorname{Pr}(H=1)=\frac{e^{X \beta^{(1)}}}{e^{X \beta^{(1)}}+e^{X \beta^{(2)}}+e^{X \beta^{(3)}}} \\
& \text { (4) } \operatorname{Pr}(H=2)=\frac{e^{X \beta^{(2)}}}{e^{X \beta^{(1)}}+e^{X \beta^{(2)}}+e^{X \beta^{(3)}}} \\
& \text { (5) } \operatorname{Pr}(H=3)=\frac{e^{X \beta^{(3)}}}{e^{X \beta^{(1)}}+e^{X \beta^{(2)}}+e^{X \beta^{(3)}}}
\end{aligned}
$$

where the outcome 1 refers to those households who participated in at least one ARA of Type 1 (Equation 3), which have the greatest potential additionality; outcome 2 refers to those households who participated in ARAs of any type except Type 1 (Equation 4); outcome 3 refers to those that did not participate in any ARA at all (Equation 5). We estimated the set of coefficients $\beta^{(1)}, \beta^{(2)}$, and $\beta^{(3)}$, corresponding to each outcomes using the maximum-likelihood estimator. In practice, 
we perform the econometric analysis using $R$ Software (R Core Team, 2018) and the following R-packages: heplots (Fox et al., 2018), maxLik (Henningsen \& Toomet, 2011), censReg (Henningsen, 2017), ggplot2 (Wickham, 2009) and nnet

(Venables \& Ripley, 2002).

\section{Results}

Overall, our results show that all three groups of factors includes variables that significantly influence the probability and the intensity of participation, with a stronger influence of economic and pro-social characteristics, while pro-environmental factors influence more strongly the participation to more stringent agreements.

\section{Probability of participation in the program and area enrolled}

Table 3 presents both the results of the logistic model of participation (model 1), as well as the results of the Tobit model (model 2).

Table 3. Summary of Logistic model of the probability of participation in ARAs and the censored Tobit model for the area enrolled in ARAs. Variables that were not included in one of the model are indicated by "n.i." ("not included"). Estimates include community dummies for each community, that are not displayed in this table in order to save space but that are displayed in Appendix 1. The code for the pvalue is $\mathbf{p}<0.01(* * *)-\mathbf{p}<0.05(* *)-\mathbf{p}<0.1\left(^{*}\right)-\mathbf{p}<0.15$ (.)

\begin{tabular}{|c|c|c|c|c|c|c|c|c|}
\hline & & & \multicolumn{3}{|c|}{$\begin{array}{l}\text { Model } 1 \\
\text { (Logit) }\end{array}$} & \multicolumn{3}{|c|}{$\begin{array}{c}\text { Model } 2 \\
\text { (Tobit) }\end{array}$} \\
\hline & \multicolumn{2}{|l|}{ Dependant variable } & \multicolumn{3}{|c|}{ Participate in ARA ( $1=$ Yes, $0=\mathrm{No})$} & \multicolumn{3}{|c|}{ Total area in the ARA (ha) } \\
\hline & Covariates & Unit/Code & Odds ratio & $\mathrm{p}$ & $95 \% \mathrm{CI}$ & Coef & $\mathrm{p}$ & $95 \% \mathrm{CI}$ \\
\hline & Intercept & & 0.01 & $* *$ & {$[0 ; 0.39]$} & -834.43 & *** & $\begin{array}{l}{[-1075.4 ;-} \\
308.3]\end{array}$ \\
\hline \multirow{14}{*}{$\begin{array}{l}0 \\
0 \\
0 \\
\tilde{0} \\
.0 \\
0 \\
0 \\
0 \\
0 \\
0\end{array}$} & Number of members & (number) & 1.05 & & {$[0.87: 1.28]$} & -2.95 & & {$[-23: 17.1]$} \\
\hline & Age of the head of the household & (years) & 0.98 & & {$[0.95 ; 1.01]$} & -1.91 & & {$[-5.2 ; 1.4]$} \\
\hline & Head of the household went to primary school & $(1=$ Yes, $0=$ No $)$ & 1.50 & & {$[0.39 ; 6.45]$} & 76.23 & & {$[-68 ; 220.4]$} \\
\hline & Head of the household went to secondary school & $(1=$ Yes, $0=\mathrm{No})$ & 0.95 & & {$[0.18 ; 5.35]$} & -4.74 & & {$[-181.9 ; 172.4]$} \\
\hline & Total land area & (ha) & 1.00 & & {$[1 ; 1]$} & 0.37 & ** & {$[0 ; 0.7]$} \\
\hline & Proportion of forested land & ( $\%$ of land area) & 17.00 & $* * *$ & {$[3.14 ; 119.74]$} & 305.43 & $* * *$ & {$[121.4 ; 489.5]$} \\
\hline & Proportion of grassland & (\% of land area) & 12.71 & . & {$[0.43 ; 341.07]$} & 297.89 & $*$ & {$[-49.5 ; 645.3]$} \\
\hline & Owns forested land & $(1=$ Yes, $0=\mathrm{No})$ & 1.93 & . & {$[0.82 ; 4.53]$} & 57.80 & & {$[-30.3 ; 145.9]$} \\
\hline & Owns cultivated land & $(1=$ Yes, $0=\mathrm{No})$ & 3.02 & $*$ & {$[1 ; 10.21]$} & 77.24 & & {$[-37.6 ; 192]$} \\
\hline & Number of cows & (number) & 0.99 & & {$[0.97 ; 1]$} & -1.07 & & {$[-2.8 ; 0.7]$} \\
\hline & Owns at least one plough & $(1=$ Yes, $0=$ No $)$ & 2.64 & $* *$ & {$[1.02 ; 6.98]$} & 87.85 & $*$ & {$[-7.6 ; 183.3]$} \\
\hline & Owns at least one tractor & $(1=$ Yes, $0=$ No $)$ & 9.00 & ** & {$[1.48 ; 53.48]$} & 268.71 & $* * *$ & {$[90.4 ; 447]$} \\
\hline & $\begin{array}{l}\text { Has a credit with a bank, or a credit union, or a } \\
\text { government fund. }\end{array}$ & $(1=$ Yes, $0=$ No $)$ & 1.47 & & {$[0.56 ; 3.81]$} & -42.01 & & {$[-141.5 ; 57.4]$} \\
\hline & Has no other income-generating activities & $(1=$ Yes, $0=$ No $)$ & 0.44 & $*$ & {$[0.18 ; 1.04]$} & -83.54 & $*$ & {$[-172.1 ; 5.1]$} \\
\hline
\end{tabular}




\begin{tabular}{|c|c|c|c|c|c|c|c|c|}
\hline \multirow{7}{*}{ 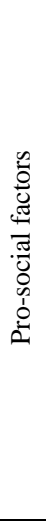 } & $\begin{array}{l}\text { Is an authority/was an authority/is a member of a } \\
\text { breeders' association }\end{array}$ & $(1=$ Yes, $0=$ No $)$ & 8.42 & *** & {$[2.55 ; 29.47]$} & 209.50 & $* * *$ & {$[82.9 ; 336.1]$} \\
\hline & Participates in collective work (Minga, Faena, Ayni) & $(1=$ Yes, $0=$ No $)$ & 4.01 & $* * *$ & {$[1.68 ; 9.99]$} & 155.86 & $* * *$ & {$[64.6 ; 247.1]$} \\
\hline & $\begin{array}{l}\text { Number of days of community work devoted to } \\
\text { water management }\end{array}$ & (number) & 1.12 & $*$ & {$[0.99 ; 1.26]$} & 16.60 & $* * *$ & {$[4.8 ; 28.4]$} \\
\hline & $\begin{array}{l}\text { Lives in the community since the generation of their } \\
\text { parents }\end{array}$ & $(1=$ Yes, $0=$ No $)$ & 1.67 & & {$[0.71 ; 4]$} & 88.04 & $*$ & {$[-0.1 ; 176.2]$} \\
\hline & $\begin{array}{l}\text { Lives in the community since the generation of their } \\
\text { grandparents }\end{array}$ & $(1=$ Yes, $0=$ No $)$ & 9.51 & $* *$ & {$[0.95 ; 89.05]$} & 341.89 & $* * *$ & {$[115.8 ; 568]$} \\
\hline & Trusts institutions and NGOs & $(1=$ Yes, $0=$ No $)$ & 0.21 & $* * *$ & {$[0.09 ; 0.48]$} & -142.55 & $* * *$ & {$[-226.7 ;-58.4]$} \\
\hline & $\begin{array}{l}\text { Thinks that decisions made by his-her community } \\
\text { are fair }\end{array}$ & $(1=$ Yes, $0=$ No $)$ & 0.30 & . & {$[0.07 ; 1.3]$} & -117.31 & & {$[-263.6 ; 29]$} \\
\hline \multirow{6}{*}{ 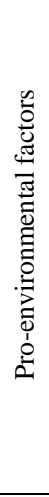 } & $\begin{array}{l}\text { Knows how his-her community can protect the } \\
\text { environment }\end{array}$ & $(1=$ Yes, $0=$ No $)$ & 3.66 & $*$ & {$[1 ; 16.49]$} & 122.91 & . & {$[-26.1 ; 271.9]$} \\
\hline & $\begin{array}{l}\text { Thinks that the forest provides fodder, non-timber } \\
\text { forest products, timber, firewood and bushmeat }\end{array}$ & $(1=$ Yes, $0=$ No $)$ & 0.33 & $* *$ & {$[0.11 ; 1.01]$} & n.i. & n.i. & n.i. \\
\hline & $\begin{array}{l}\text { Thinks that the forest brings rain, maintains water } \\
\text { quality, maintains water quantity, stabilizes the } \\
\text { climate }\end{array}$ & $(1=$ Yes, $0=$ No $)$ & 2.19 & $*$ & {$[0.99 ; 5.02]$} & 108.51 & $* *$ & {$[23.1 ; 193.9]$} \\
\hline & Thinks that the forest brings a nice view & $(1=$ Yes, $0=$ No $)$ & 5.40 & $*$ & {$[0.79 ; 33.5]$} & n.i. & n.i. & n.i. \\
\hline & $\begin{array}{l}\text { Environmental protection is an important value that } \\
\text { he wants to teach his-her children }\end{array}$ & $(1=$ Yes, $0=$ No $)$ & 0.39 & $* *$ & {$[0.16 ; 0.89]$} & -67.51 & & {$[-152.4 ; 17.4]$} \\
\hline & $\begin{array}{l}\text { Wants support for water and environmental } \\
\text { management }\end{array}$ & $(1=$ Yes, $0=\mathrm{No})$ & 2.70 & *** & {$[1.08 ; 6.9]$} & 109.76 & $* *$ & {$[16.6 ; 202.9]$} \\
\hline & & AIC & \multicolumn{3}{|c|}{325.29} & \multicolumn{3}{|c|}{1225.01} \\
\hline & & Mc Fadden $\mathrm{R}^{2}$ & \multicolumn{3}{|c|}{0.45} & \multicolumn{3}{|c|}{0.17} \\
\hline
\end{tabular}

Sample size: 424 households including 74 that participated in ARAs

Our results suggest that economic factors had an important influence on the decision to participate and the area enrolled.

Firstly, we found that the households that had a greater proportion of forest on their land had a greater probability to enter into ARAs and dedicate a greater area to conservation. We also estimated an alternative model using the absolute area of forestland instead of the proportion of forestland (Appendix 1). We did not find a big influence of the absolute area of forested land on the probability of participation (the odds ratio almost equals one in the logit model), while we found that for each additional hectare of forestland, the households contributed on average 0.6 ha more to conservation effort (Tobit model).

Results displayed in Appendix 1 moreover suggest that forest ownership may have affected households' participation in the program $^{6}$. We estimated an alternative model replacing the forest ownership variable with a dummy variable taking on the value of one for households that own forests they do not use because the land is not suitable for other purposes, and zero for households that do not have any unexploited forests or that have but do not use it for other reasons (Appendix 2). In particular, we found that households that owned forests that they did not use because they considered it as not suitable for agricultural purposes involved an average of 150 additional hectares in the program (Tobit model in Appendix 2). 
Further, households having more means of production in the form of agricultural tools were also more likely to participate and dedicate a greater area to conservation. Households that had no other sources of income apart from agriculture were also less likely to participate and allocated fewer hectares under conservation.

The pro-social factors influencing participation included variables about integration into the community and into its social networks, as well as reciprocal interactions and institutional trust. Having been a member of a breeders' association strongly influenced the probability of participation and area enrolled in the program. A household that was part of a livestock association was about 8.5 times more likely to participate in the ARAs, and put about 210 hectares more under conservation.

Families who had been part of the community since at least the generation of their grandparents were about 10 times more likely to participate, and on average put 340 ha supplementary under conservation. Reciprocity also strongly influenced the probability of participation and area enrolled. Households that participated in at least one form of collective agricultural work (Minga, Faena or Ayni) were more likely to participate in any type of ARA and on average contributed an additional 160 hectares to conservation. Similarly, the number of days of community work dedicated to water management had a statistically significant (though small) positive impact on the probability of participation and on the area under conservation. For each additional day of collective work in water management, we expect to see about a $12 \%$ increase in the odds of participating in the program, and 17 additional hectares under conservation. Finally, institutional trust had a significant and negative impact on the probability of participation and on the area enrolled in the program.

Regarding pro-environmental factors, we found that household heads who stated that forest provide them with climate and water cycle regulation services were about twice more likely than others to participate in ARAs and committed an average of 100 ha more to conservation. Surprisingly, the cultural service of landscape beauty had a stronger positive influence on participation than the perception of the water and climate regulation services, although the natural beauty of landscape was not an argument used by Natura when offering to participate in the program. In contrast, households citing provisioning services provided by forests (e.g. fuelwood, timber, bushmeat, non-timber forest products and fodder) were about three times less likely to participate.

Knowledge about the environment, in terms of how it works, the threats it faces and the possible solutions, appeared to be another important psychosocial determinant of participation in the program. Households who believed that they knew how their community could protect the environment were three times more likely to participate in the program and contributed an average of 120 ha more to conservation. The variable related to awareness about water or environmental problems was 
not included in our final models as it had no significant influence on participation and did not improve the model fit. However, households that requested support from visiting institutions for the management of water or the environment participated more in all types of ARAs and committed more land to conservation

Some variables that were expected to influence participation finally had no significant impacts in the various model specifications tested. It was for example the case of the idea that it is up to the government to implement laws that determine what people can do with their land to protect the environment. Also, personal pro-environmental moral norms - prioritizing environmental protection as a value to transmit to their children among other values- had a negative influence on the probability of participation, contrary to our assumptions.

\section{Decision to participate in most stringent ARA (Type 1)}

Table 4 presents the results of the multinomial logistic model. This model takes as reference the households that did not participate in any agreement. The odds ratios displayed in column 1 refer to households that have participated in at least one Type 1 agreement (compared to those that have not participated in any agreement). The odds ratios in column 2 refer to those households who participated in ARAs of any type except Type 1 (compared to those that have not participated in any agreement).

Beyond the variables already mentioned in the previous results that make it possible to distinguish households participating in any agreements and area enrolled without distinction of the different types, some other factors, mainly pro-environmental ones, precisely differentiate households that participate in Type 1 agreements. Households that participated in at least one agreement of Type 1 generally had knowledge about what their community could do to protect the environment, wanted support for managing environmental or water problems but agreed that damaging the environment is somehow necessary to improve their standard of living. They also generally disagreed that if their neighbours did nothing for the environment, they should do nothing either. In addition, the recognition that forests provide a beautiful view (cultural ecosystem service) was the variable with the greatest positive effect on participation into Type 1 agreements.

Regarding economic factors, not having access to other income-generating activities strongly decreased the probability of participation into Type 1 ARAs. We did not detect an effect from the number of cows owned by households. This result appears counter-intuitive since, as Type 1 ARAs demand farmers to exclude cattle from the surface under the agreement, a larger number of cows could provide negative incentives to participate to such an agreement. However, this variable was 
strongly correlated to the total land area (Pearson correlation $\left.=0.538^{* * *}\right)$ and the proportion of forested land (Pearson correlation $\left.=0.331^{* * *}\right)$. When removing these variables, the variable number of cows become significantly positive, suggesting that it reflects a higher participation of richer households.

Regarding pro-social variables, we found that those households who believe that people in one's own community cooperate to solve common problems (stronger perception of cooperation norms within community) had opted for Type 1 ARAs more often than others.

Table 4. Summary of the multinomial Logistic model of participation in the different types of ARAs. The reference level are the households that have not participated in any kind of ARAs $(n=341)$. Estimates include community dummies for each community, but these are not displayed in this table in order to save space. Two variables do not have enough variability to calculate their coefficients, which are coded as "n.a.". The code for the p-value is $\mathbf{p}<0.01(* * *)-\mathbf{p}<0.05(* *)-\mathbf{p}<0.1(*)-\mathbf{p}<0.15$ (.)

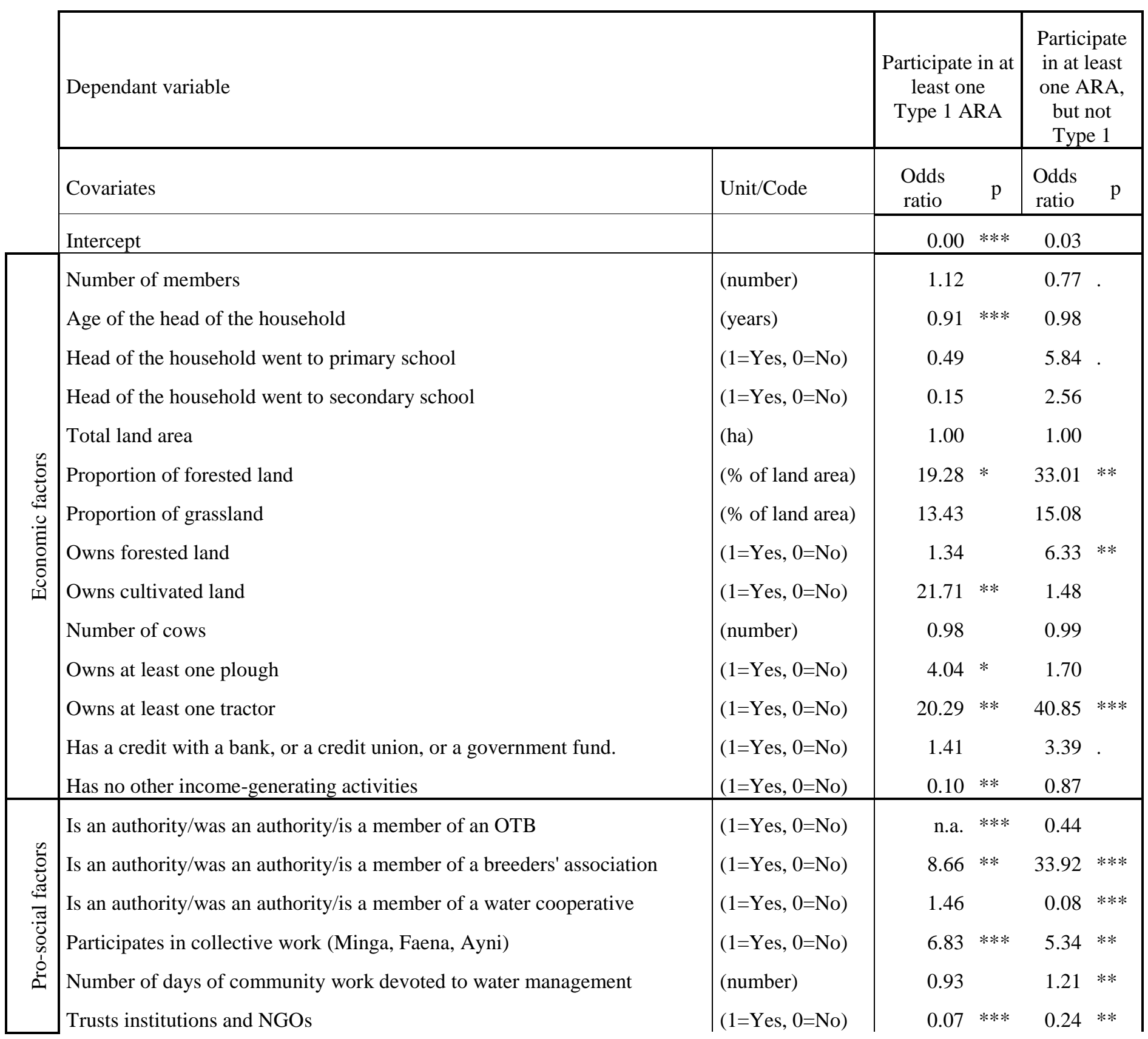




\begin{tabular}{|c|c|c|c|c|c|c|}
\hline & $\begin{array}{l}\text { Agrees that "People in his community work together to solve common } \\
\text { problems" } \\
\text { Thinks that decisions made by his-her community are fair }\end{array}$ & $\begin{array}{l}(1=\text { Yes, } 0=\mathrm{No}) \\
(1=\text { Yes, } 0=\mathrm{No})\end{array}$ & $\begin{array}{l}4.91 \\
0.74 \\
\end{array}$ & $*$ & $\begin{array}{l}0.34 \\
0.10 \\
\end{array}$ & ** \\
\hline \multirow{10}{*}{ 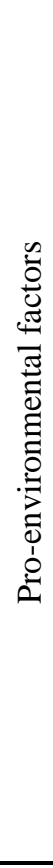 } & $\begin{array}{l}\text { Agrees that "to improve living conditions, it is necessary to damage the } \\
\text { environment." }\end{array}$ & $(1=$ Yes, $0=$ No $)$ & 7.46 & $* * *$ & 0.41 & \\
\hline & $\begin{array}{l}\text { Agrees that "If your neighbours do nothing for the environment, you } \\
\text { should do nothing either." }\end{array}$ & $(1=$ Yes, $0=$ No $)$ & 0.20 & $*$ & 2.09 & \\
\hline & Is in favour of the imposition of forest standards by the government & $(1=$ Yes, $0=$ No $)$ & n.a. & $* * *$ & 1.00 & \\
\hline & Knows how his-her community can protect the environment & $(1=$ Yes, $0=$ No $)$ & 5.95 & $*$ & 5.48 & . \\
\hline & $\begin{array}{l}\text { Thinks that the forest provides fodder, non-timber forest products, timber, } \\
\text { firewood and bush meat }\end{array}$ & $(1=$ Yes, $0=\mathrm{No})$ & 0.27 & & 0.28 & . \\
\hline & $\begin{array}{l}\text { Thinks that the forest brings rain, maintains water quality, maintains water } \\
\text { quantity, stabilizes the climate }\end{array}$ & $(1=$ Yes, $0=\mathrm{No})$ & 2.54 & & 3.42 & * \\
\hline & Thinks that the forest brings a nice view & $(1=$ Yes, $0=$ No $)$ & 31.87 & $* *$ & 4.50 & \\
\hline & $\begin{array}{l}\text { Environmental protection is an important value that he wants to teach his- } \\
\text { her children }\end{array}$ & $(1=$ Yes, $0=$ No $)$ & 0.44 & & 0.27 & * \\
\hline & Wants support for water and environmental management & $(1=$ Yes, $0=$ No $)$ & 4.50 & $* *$ & 2.92 & \\
\hline & $\begin{array}{l}\text { Thinks that the destruction of the environment is a major challenge for his- } \\
\text { her community }\end{array}$ & $(1=$ Yes, $0=$ No $)$ & 0.28 & . & 2.32 & \\
\hline & & $\begin{array}{l}\text { Residual } \\
\text { Deviance }\end{array}$ & & 235 & & \\
\hline & & AIC & & 451. & & \\
\hline & & Mc Fadden $\mathrm{R}^{2}$ & & 0.5 & & \\
\hline
\end{tabular}

Sample size: 421 households including 34 that have participated in at least one Type 1 agreement and 37 that participated in ARAs of any type except Type 1. 


\section{Discussion}

\section{The advantage of wealthier households owning large forests}

Overall, the economic factors seem to have operated mainly as a mix of barriers and incentives that favoured better-off people, having property titles, owning more forested land, more means of production in the form of agricultural tools and access to off-farm income-generating activities. Grillos (2017) and Bremer et al., (2014) also found similar evidence.

The influence of the proportion of forested land on participation may have acted both as a barrier to entry for households that do not own forested land or an opportunity cost for households with a low proportion of forested land, and as a an economic incentive for richer households having more forested land as they could enroll a higher forested area in ARAs and receive a greater amount of compensation. Access to off-farm income-generating activities also increased the possibility of dedicating land to conservation.

Other studies have already warned about the risk that PES may exclude poor households because of eligibility requirements - such as access to land and formal property rights-, higher relative transaction costs and initial investments to adopt new pro-environmental practices, and higher opportunity cost - income lost from agriculture and other forest-resource-use activities (Landell-Mills \& Porras, 2002; Wunder, 2008; Lee \& Mahanty, 2009; Zbinden \& Lee, 2005; Pagiola et al., 2005; Grieg-Gran et al., 2005). Indeed, concerning this last point, forests are a crucial source of income and income diversification in tropical developing countries (Vedeld et al., 2007; Wunder, Angelsen, \& Belcher, 2014) and a financial safety net for the poorest in times of scarcity or emergency (Angelsen and Wunder, 2003; Cavendish, 2003), which increases the relative opportunity cost for poorer households to participate in agreements, which could outweigh the value of the compensation.

Our results also underline the importance of owning unused forests with a low opportunity cost in the decision to participate and to enrol a large area to conservation in the program. In both the Logistic and the Tobit models, the variable that referred to the ownership of unused and low opportunity cost forests had a large, positive and significant coefficient. This result suggests that the probability of participating is not dependent on simply owning a forest, but owning forests that are not exploited because they are not suitable for agricultural uses. In another study of ARA in Bolivia, 39\% of Type 1 agreements and $14 \%$ of Type 2 and 3 agreements were actually additional, i.e. agreements that were respected and were not enrolled on land unsuitable for agriculture or grazing and that people would not have used in the absence of the program (Bottazzi et al., 2018). Although we are not able to estimate the additionality of the ARAs in this study, our results suggest that, similar 
to other incentive-based conservation programs (Börner et al., 2017), the program may have enrolled farmers owning a large proportion of eligible land with a low opportunity cost, or land that they would not have used anyway (Pattanayak et al., 2010; Sánchez-Azofeifa et al., 2007; Arriagada et al., 2009; Figueroa et al., 2016).

These results may have two main implications for the success of the program. First, the entry barriers likely reduced the number of hectares of forest that could have been engaged and the environmental additionality of the project, because poor, small landholders or those who have no other income from non-farming activities may not have been able to enroll some forests with a relatively higher opportunity cost. Second, in such a context where many inequalities already exist within communities, non-participating households (or participants who can only enroll a small area) could perceive as a distributional justice problem the fact that better-off households received higher compensation for large areas they did not intend to use in the absence of the program while poorer and more forest-dependent households could not participate. Perception of inequity in access to or distribution of compensations may have a negative impact on the number of households willing to participate and on the quality of relationships between privileged participants and non-participants and thus deteriorate the community's social capital and intrinsic motivations for pro-social and pro-environmental behaviours, which could undermine the program's conservation success (Landell-Mills \& Porras, 2002; Wunder, 2008 ; Pascual et al., 2014, Ezzine-de-Blas et al., 2019).

To avoid these problems, the value of compensation per hectare could be adjusted according to the relative opportunity cost and additionality of the hectares of forest that households wish to engage in the program (e.g. according to the location of forests on steep and rocky slopes that cannot be cultivated versus on low slopes with deeper soil and according to the economic status of the household). Another way to increase the equity of the program and its environmental performance would be to allow households without individual property title to participate on the communal land they use. The latter option is currently under consideration by Natura.

\section{The commitment of socially-engaged and long-established households}

Several pro-social variables - integration into social and reciprocal networks as well as seniority - appeared to have a significant effect on participation and intensity of participation in the program, which suggests that the ARA program succeeded in building on pro-social motivations to encourage participation. These results differ from those of Bottazzi et al., (2018) in another area of Bolivia, who studied the self-reported motivations of ARA participants after their decision to participate. In their analysis, pro-social motivations were the least cited reasons for entering into the program and did not 
have a statistically significant effect on the decision to participate. In contrast, in our study where pro-social attitudes of households were measured before their decision to participate, pro-social factors did influence the participation, with effects as strong (in magnitude) as some economic variables.

The positive influence of farmers' integration into social and reciprocal networks in the likelihood to participate in the program may operate by increasing the altruistic pro-social motivations for participation. Such network integration could also increase the access to information about projects (existence about the project and how to enter in it) (Bremer et al., 2014) or about environmental problems, and therefore contribute to a greater environmental awareness (Cramb, 2005; Wakefield et al., 2006). The generation (or seniority) effect underlined in our analysis may be because people who have lived longer in a community are more integrated into social networks and have more pro-social motivations to enter the program. It may also reflect that they are more emotionally bound to their environment and community and are more motivated to take care of it. This feeling of belonging, also called a "sense of place" in the literature, refers to feelings of identity, attachment and dependence to specific places (Jorgensen \& Stedman 2001; Stedman 2002) and is related to proenvironmental concerns and behaviours regarding these places (Terry et al., 1999; Clayton, 2003; van der Werff et al., 2013; Stedman, 2002; Noorgaard, 2011; Fraser et al., 2009...) especially if they are threatened (Manzo \& Devine-Wright, 2013; Clayton \& Opotow, 2003; Kim \& Kaplan, 2004). This feeling develops through direct experiences with the physical environment (Proshansky et al., 1983), intimate episodes (Tuan 1977), the duration of residence in a place, or cultural or ancestral bonds with a place (Hay 1998). In the literature, it has been shown to be stronger for people who have grown up in a place or have lived longer there (Terry et al., 1999; Clayton, 2003; van der Werff et al., 2013; Stedman, 2002; Noorgaard, 2011; Fraser et al., 2009).

\section{The counter-intuitive effect of institutional trust}

We detected a statistically significant negative effect of trust in institutions and NGOs on households' decision to participate and enrol large areas in the program, which was contrary to our hypotheses. In several previous studies, institutional trust had a positive influence on pro-environmental behaviour and on participation in conservation programs (Groothuis \& Miller, 1997; Petts, 1998; Beierle \& Cayford, 2002; Jones et al., 2009a). Indeed, people who trust institutions were more confident that they will receive the payment offered, and did not fear expropriation of their land (Miranda et al., 2003; Southgate \& Wunder, 2009). In our case, it is possible that the lack of trust in institutions and NGOs could encourage individuals to address such institutional failures by committing themselves to pro-environmental actions. This would be in line with the 
higher participation we observe in our data among households who think that the decisions made by their community are unfair. This poses a dilemma. On the one hand, a lack of trust in institutions may incentivize households to engage with new programs. On the other hand, a lack of social capital may reduce the capacity of communities to address common problems of collective action in the long term and thus affect the success of conservation interventions (Cranford \& Mourato, 2011). Reconciling these two dynamics might prove challenging in contexts where farmers seem not to believe in local institutions and communal decisions, and because pro-social motivations related to social capital can be subject to crowdingout by economic incentives (Rode et al., 2015).

\section{The influence of environmental consciousness}

In line with our assumptions derived from Bamberg's \& Möser's (2007) pro-environmental factors and the SelfDetermination Theory (Ezzine-de-Blas et al., 2019), we found that some pro-environmental motivations positively influenced households' decision to participate and the intensity of participation. In contrast, Grillos (2017), studying the same program in another study area, found no significant influence of pro-environmental motivation when controlling for social and material factors.

Households who valued the regulating and cultural ecosystem services provided by forest participated with higher probability and intensity. This positive influence of the perception of water ecosystem services is in line with Bremer et al., (2014) and Bottazzi et al., (2018) who showed that the perception of water services provided by conserving the forest $-\mathrm{a}$ utilitarian pro-environmental motivation - was one of the main motivations for entering an incentive-based conservation program in Ecuador and Bolivia. On the contrary, those households who valued provisioning ecosystem services such as fodder, non-timber forest products, timber, firewood and bushmeat participated less. Indeed, as the agreements signed by households specified that they were not allowed to extract plants and natural fertilizers (dead leaves and humus), hunt animals or cut trees for commercial uses, households that valued more highly these provisioning services might evaluate the balance between gains and losses of ecosystem services and consider that engaging in a conservation agreement would represent a loss of benefits, which would reduce their attitude towards participation. This indicates that the households can well perceive and evaluate the implications on ecosystem services of their decision to participate in an agreement (Meyfroidt, 2013). The importance of farmers' cognition of ecosystem services - i.e. their knowledge about and evaluation of ecosystem services - in their conservation decisions was also showed in other contexts, such as the French Alps (Lamarque et al., 2014). 
We found that households who allocated the greatest area to the agreements were aware of environmental problems, had the perception that they have knowledge about what can be done to protect the environment, would like the situation to change and prioritized this problem among others - since they would specifically request support for water and environmental management if NGOs offered them the opportunity to do so. Regarding the most stringent agreements, we moreover found that the participants feel a greater individual responsibility to act (they stated they would not do the same as their neighbours if the latter did nothing for the environment). However, they may also have a low perceived competence (SDT of Ryan \& Deci, 2000, expanded by Ezzine-de-Blas et al., 2019) or a low perception of behavioural control (Bamberg \& Möser, 2007) to be able to act more pro-environmentally, since as they believed that improving their standard of living was necessarily linked to degrading the environment.

Both concepts derive from the concept of self-efficacy (Bandura, 1982) defined as "the belief in one's capabilities to organize and execute courses of action required to produce given attainments" (Bandura, 2003), which mediates the link between attitudes or intentions and behaviors (Bandura 2003; Armitage \& Conner 2001). According to this concept, low self-efficacy belief hinders actions in a related domain, which means that actors who believe that they do not have control over their behaviour or the capacity to change it will act less pro-environmentally or will have fewer incentives to do so. In addition to being correlated with knowledge (Meinhold \& Malkus, 2005), self-efficacy is normally positively associated with engagement in pro-environmental behaviours (Spence et al., 2011; Hines et al., 1987) and has a mediating role between knowledge and engagement in pro-environmental behaviour (Bamberg \& Möser, 2007). Our results show the contrary: households with knowledge about environmental problems and solutions but low self-efficacy are more likely to enter into more restrictive conservation agreements. Our assumption is that the program, which compensates households that give up the benefit of deforestation by offering ways of developing without degrading the forest, could precisely appeal to these individuals by increasing their perceived behavioural control and competence by learning about (and how to implement) development alternatives and receiving materials to do it.

\section{Further research}

Future investigation could use structural equation modelling (SEM) (Kaplan, 2008) to gain a deeper understanding of the motivations to participation by exploring the psychological mechanisms that underlie the psycho-social constructs studied in this analysis and the associated environmental behaviours. Further clarifying the motivations leading to deforestation could also contribute to improve our understanding of potential gaps between conservation decisions and actual land-use 
behaviours, and to identify the most effective motivational drivers of conservation (Kollmuss \& Agyeman, 2002). Landuse practices such as deforestation are influenced by a broad range of processes and factors embedded in a larger structural, historical, social, cultural, institutional, economic and technical context. Future research would thus benefit from combining the psycho-social approach used in this study with the broader and less individual-centred sociological literature on practices and habits related to the environment (Shove, 2010, 2012). This understanding is of crucial importance for being able to implement conservation interventions or policies that truly succeed in changing the dynamics at work behind environmental behaviours in the long term.

\section{Conclusions}

The effectiveness of incentive-based programs for conservation depends on how they interact with multiple motivations of the participants, in order to have a sufficient participation rate, to avoid the crowding out of intrinsic motivations, and to generate desired pro-environmental behaviours that will sustain on the long term. In this article, we studied an in-kind incentive-based conservation program that mixes material incentives with pro-social motivations based on reciprocity and pro-environmental motivations related to forest ecosystem services. Drawing on three perspectives of the scientific literature on pro-environmental decisions, we have identified a number of determinants, which include economic factors, pro-social factors likely to promote collective action and social capital, and pro-environmental factors likely to trigger engagement in environmentally responsible behaviour. We found that those levers are likely to influence the probability to participate voluntarily in the program, the area engaged into the program and the probability to enrol in the most restrictive agreements.

Our results are in line with the literature suggesting that motivations related to incentive-based conservation do not come only and directly from economic incentives (Bottazzi et al., 2018; Grillos, 2017; Figueroa et al., 2016; Rode et al., 2015; Hayes, $2012 ; \ldots$ ). In particular, we found that economic incentives and barriers favoured the probability of participation of better-off households with property titles, more forested land, more agricultural tools and access to alternative income, and the intensity of their participation. We moreover found that pro-social factors, related to a deeper or older integration into social networks, greater compliance to social norms of reciprocity and weaker institutional trust, play a role at least as important.

Finally, we found that pro-environmental factors such as awareness of environmental problem, greater knowledge about solutions and a positive evaluation of ecosystem services provided by forest conservation may influence positively the 
probability to participate and the intensity of participation, while greater individual responsibility and weaker perceived behavioural control increased the participation into more stringent and more rewarding agreements. Our results suggest that the program needs also to reflect on ways to reduce entry barriers for poorer households and to increase additionality. 


\section{References}

Angelsen, A., \& Wunder, S. (2003). Exploring the forest—poverty link. CIFOR occasional paper, 40, 1-20.

Arriagada, R. A., Sills, E. O., Pattanayak, S. K., \& Ferraro, P. J. (2009). Combining qualitative and quantitative methods to evaluate participation in Costa Rica's program of payments for environmental services. Journal of Sustainable Forestry, 28(3-5), 343-367.

Asquith, N. (2016). Watershared: adaptation, mitigation, watershed protection and economic development in Latin America. Inside stories on climate compatible development.

Balthazar, V., Vanacker, V., Molina, A., \& Lambin, E. F. (2015). Impacts of forest cover change on ecosystem services in high Andean mountains. Ecological indicators, 48, 63-75.

Bamberg, S., \& Möser, G. (2007). Twenty years after Hines, Hungerford, and Tomera: A new meta-analysis of psychosocial determinants of pro-environmental behaviour. Journal of environmental psychology, 27(1), 14-25.

Bandura, A. (1982). Self-efficacy mechanism in human agency. American psychologist, 37(2), 122.

Bandura, A., \& Locke, E. A. (2003). Negative self-efficacy and goal effects revisited. Journal of applied psychology, $88(1), 87$.

Bathurst, J. C., Amezaga, J., Cisneros, F., Gaviño Novillo, M., Iroumé, A., Lenzi, M. A., ... \& Urciuolo, A. (2010). Forests and floods in Latin America: science, management, policy and the EPIC FORCE project: In memoriam: Ian Rainy Calder (1945-2009). Water International, 35(2), 114-131.

Beierle, T. C., \& Cayford, J. (2002). Democracy in practice: Public participation in environmental decisions. Washington, DC: RFF Press.

Benabou, R., \& Tirole, J. (2003). Intrinsic and extrinsic motivation. The review of economic studies, 70(3), 489-520.

Bonnesoeur, V., Locatelli, B., Guariguata, M. R., Ochoa-Tocachi, B. F., Vanacker, V., Mao, Z., ... \& Mathez-Stiefel, S. L. (2019). Impacts of forests and forestation on hydrological services in the Andes: A systematic review. Forest Ecology and Management, 433, 569-584.

Börner, J., Baylis, K., Corbera, E., Ezzine-de-Blas, D., Honey-Rosés, J., Persson, U. M., \& Wunder, S. (2017). The effectiveness of payments for environmental services. World Development, 96, 359-374.

Bottazzi, P., Wiik, E., Crespo, D., \& Jones, J. P. (2018). Payment for Environmental "Self-Service": Exploring the Links Between Farmers' Motivation and Additionality in a Conservation Incentive Programme in the Bolivian Andes. Ecological Economics, 150, 11-23.

Bourdieu, P. (1986). The forms of capital. In J. G. Richardson (Ed.), Handbook of theory and research for the sociology of education, 241-258, New York: Greenwood Press.

Bowles, S., \& Gintis, H. (2002). Social capital and community governance. The economic journal, 112(483), F419F436.

Bowles, S., \& Polania-Reyes, S. (2012). Economic incentives and social preferences: substitutes or complements?. Journal of Economic Literature, 50(2), 368-425.

Bremer, L. L., Farley, K. A., \& Lopez-Carr, D. (2014). What factors influence participation in payment for ecosystem services programs? An evaluation of Ecuador's SocioPáramo program. Land Use Policy, 36, 122-133.

Cavendish, W. (2003). How do forests support, insure and improve the livelihoods of the rural poor? A research note. Center for International Forestry Research. Bogor, Indonesia. 
Célleri, R., \& Feyen, J. (2009). The hydrology of tropical Andean ecosystems: importance, knowledge status, and perspectives. Mountain Research and Development, 29(4), 350-356.

Chen, X., Lupi, F., An, L., Sheely, R., Viña, A., \& Liu, J. (2012). Agent-based modeling of the effects of social norms on enrollment in payments for ecosystem services. Ecological modelling, 229, 16-24.

Clayton, S. (2003). Environmental identity: A conceptual and an operational definition. Identity and the natural environment: The psychological significance of nature, 45-65.

Clayton, S., \& Opotow, S. (2003). Introduction: Identity and the Natural Environment, pp 1-24, Cambridge, MA:MIT.

Cramb, R. A. (2005). Social capital and soil conservation: evidence from the Philippines. Australian Journal of Agricultural and Resource Economics, 49(2), 211-226.

Cranford, M., \& Mourato, S. (2011). Community conservation and a two-stage approach to payments for ecosystem services. Ecological economics, 71, 89-98.

Crilly, D., Schneider, S. C., \& Zollo, M. (2008). Psychological antecedents to socially responsible behaviour. European Management Review, 5(3), 175-190.

De Janvry, A., \& Sadoulet, E. (2006). Progress in the modeling of rural households' behaviour under market failures. In Poverty, inequality and development, pp. 155-181, Springer, Boston, MA.

Ellison, D., Morris, C. E., Locatelli, B., Sheil, D., Cohen, J., Murdiyarso, D., ... \& Gaveau, D. (2017). Trees, forests and water: Cool insights for a hot world. Global Environmental Change, 43, 51-61.

Engel, S., \& Palmer, C. (2008). Payments for environmental services as an alternative to logging under weak property rights: The case of Indonesia. Ecological Economics, 65(4), 799-809.

Ezzine-de-Blas, D., Corbera, E., \& Lapeyre, R. (2019). Payments for environmental services and motivation crowding: Towards a conceptual framework. Ecological Economics, 156, 434-443.

Ezzine-de-Blas, D., Wunder, S., Ruiz-Pérez, M., \& del Pilar Moreno-Sanchez, R. (2016). Global patterns in the implementation of payments for environmental services. PloS one, 11(3), e0149847.

Farley, J., \& Costanza, R. (2010). Payments for ecosystem services: from local to global. Ecological economics, 69(11), 2060-2068.

Fehr, E., \& Fischbacher, U. (2004). Third-party punishment and social norms. Evolution and human behaviour, 25(2), 63-87.

Figueroa, F., Caro-Borrero, Á., Revollo-Fernández, D., Merino, L., Almeida-Leñero, L., Paré, L., ... \& Mazari-Hiriart, M. (2016). "I like to conserve the forest, but I also like the cash". Socioeconomic factors influencing the motivation to be engaged in the Mexican Payment for Environmental Services Programme. Journal of forest economics, 22, 36-51.

Fox J., Friendly M., Monette G. (2018). heplots: Visualizing Tests in Multivariate Linear Models. R package version 1.3-5. URL https://CRAN.R-project.org/package=heplots

Fraser, J., Clayton, S., Sickler, J., \& Taylor, A. (2009). Belonging at the zoo: Retired volunteers, conservation activism and collective identity. Ageing \& Society, 29(3), 351-368.

Frey, B. S., \& Oberholzer-Gee, F. (1997). The cost of price incentives: An empirical analysis of motivation crowdingout. The American economic review, 87(4), 746-755. 
García-Amado, L. R., Pérez, M. R., \& García, S. B. (2013). Motivation for conservation: assessing integrated conservation and development projects and payments for environmental services in La Sepultura Biosphere Reserve, Chiapas, Mexico. Ecological Economics, 89, 92-100.

García-Amado, L. R., Pérez, M. R., Escutia, F. R., García, S. B., \& Mejía, E. C. (2011). Efficiency of payments for environmental services: equity and additionality in a case study from a biosphere reserve in Chiapas, Mexico. Ecological Economics, 70(12), 2361-2368.

Global Forest Watch. "Land cover in Bolivia”. Accessed on 04/03/2019, from www.globalforestwatch.org.

Grieg-Gran, M., Porras, I., \& Wunder, S. (2005). How can market mechanisms for forest environmental services help the poor? Preliminary lessons from Latin America. World development, 33(9), 1511-1527.

Grillos, T. (2017). Economic vs non-material incentives for participation in an in-kind payments for ecosystem services program in Bolivia. Ecological Economics, 131, 178-190.

Grima, N., Singh, S. J., Smetschka, B., \& Ringhofer, L. (2016). Payment for Ecosystem Services (PES) in Latin America: Analysing the performance of 40 case studies. Ecosystem Services, 17, 24-32.

Guns, M., \& Vanacker, V. (2013). Forest cover change trajectories and their impact on landslide occurrence in the tropical Andes. Environmental earth sciences, 70(7), 2941-2952.

Hayes, T. M. (2012). Payment for ecosystem services, sustained behavioural change, and adaptive management: peasant perspectives in the Colombian Andes. Environmental Conservation, 39(2), 144-153.

Henningsen A. \& Toomet O. (2011). maxLik: A package for maximum likelihood estimation in R. Computational Statistics 26(3), 443-458.

Henningsen, A. (2017). censReg: Censored Regression (Tobit) Models. R package version 0.5. http://CRAN.RProject.org/package=censReg.

Hines, J. M., Hungerford, H. R., \& Tomera, A. N. (1987). Analysis and synthesis of research on responsible environmental behaviour: A meta-analysis. The Journal of environmental education, 18(2), 1-8.

Ibisch, P. L., Beck, S. G., Gerkmann, B., \& Carretero, A. (2003). La diversidad biológica, pp. 47-88. In: Ibisch, P. L. \& G. Mérida (Editores). Biodiversidad: La Riqueza de Bolivia. Estado de conocimiento y conservación. Ministerio de Desarrollo sostenible, Editorial Fundación Amigos de la Naturaleza, Santa Cruz de la Sierra, Bolivia.

Jin, M. (2013). Does social capital promote pro-environmental behaviours? Implications for collaborative governance. International Journal of Public Administration, 36(6), 397-407.

Jones, N. (2010). Investigating the influence of social costs and benefits of environmental policies through social capital theory. Policy Sciences, 43(3), 229-244.

Jones, N., Halvadakis, C. P., \& Sophoulis, C. M. (2011). Social capital and household solid waste management policies: a case study in Mytilene, Greece. Environmental Politics, 20(2), 264-283.

Jones, N., Malesios, C., \& Botetzagias, I. (2009a). The influence of social capital on willingness to pay for the environment among European citizens. European Societies, 11(4), 511-530.

Jones, N., Sophoulis, C. M., Iosifides, T., Botetzagias, I., \& Evangelinos, K. (2009b). The influence of social capital on environmental policy instruments. Environmental Politics, 18(4), 595-611.

Kaplan, D. (2008). Structural equation modeling: Foundations and extensions (Vol. 10). Sage Publications. 
Kim, J., \& Kaplan, R. (2004). Physical and psychological factors in sense of community: New urbanist Kentlands and nearby Orchard Village. Environment and behaviour, 36(3), 313-340.

Kollmuss, A., \& Agyeman, J. (2002). Mind the gap: why do people act environmentally and what are the barriers to proenvironmental behaviour?. Environmental education research, 8(3), 239-260.

Landell-Mills, N., \& Porras, I. T. (2002). Silver bullet or fools' gold?: a global review of markets for forest environmental services and their impact on the poor.

Lee, E., \& Mahanty, S. S. (2009). Payments for environmental services and poverty reduction: risks and opportunities.

Levine, J., Chan, K. M., \& Satterfield, T. (2015). From rational actor to efficient complexity manager: Exorcising the ghost of Homo economicus with a unified synthesis of cognition research. Ecological Economics, 114, 22-32.

Manzo, L. C., \& Devine-Wright, P. (2013). Place attachment: Advances in theory, methods and applications. Routledge.

Meinhold, J. L., \& Malkus, A. J. (2005). Adolescent environmental behaviours: Can knowledge, attitudes, and selfefficacy make a difference?. Environment and behaviour, 37(4), 511-532.

Miranda, M., Porras, I. T., \& Moreno, M. L. (2003). The social impacts of payments for environmental services in Costa Rica: a quantitative field survey and analysis of the Virilla watershed, No. 1. IIED.

Moros, L., Vélez, M. A., \& Corbera, E. (2019). Payments for ecosystem services and motivational crowding in Colombia's Amazon Piedmont. Ecological economics, 156, 468-488.

Muradian, R. (2013). Payments for ecosystem services as incentives for collective action. Society \& Natural Resources, 26(10), 1155-1169.

Muradian, R., Corbera, E., Pascual, U., Kosoy, N., \& May, P. H. (2010). Reconciling theory and practice: An alternative conceptual framework for understanding payments for environmental services. Ecological economics, 69(6), 1202-1208.

Neuteleers, S., \& Engelen, B. (2015). Talking money: How market-based valuation can undermine environmental protection. Ecological Economics, 117, 253-260.

Ostrom, E. (1998). A behavioural approach to the rational choice theory of collective action, American political science review, 92(1), 1-22.

Ostrom, E., \& Ahn, T. K. (2009). The meaning of social capital and its link to collective action. Handbook of social capital: The troika of sociology, political science and economics, 17-35.

Pagiola, S., Arcenas, A., \& Platais, G. (2005). Can payments for environmental services help reduce poverty? An exploration of the issues and the evidence to date from Latin America. World development, 33(2), 237-253.

Pagiola, S., Rios, A. R., \& Arcenas, A. (2008). Can the poor participate in payments for environmental services? Lessons from the Silvopastoral Project in Nicaragua. Environment and Development Economics, 13(3), 299-325.

Pascual, U., Phelps, J., Garmendia, E., Brown, K., Corbera, E., Martin, A., ... \& Muradian, R. (2014). Social equity matters in payments for ecosystem services. Bioscience, 64(11), 1027-1036.

Pattanayak, S. K., Wunder, S., \& Ferraro, P. J. (2010). Show me the money: do payments supply environmental services in developing countries?. Review of environmental economics and policy, 4(2), 254-274.

Petts, J. (1998). Trust and waste management information expectation versus observation. Journal of Risk Research, 1(4), 307-320. 
Pretty, J. (2003). Social capital and the collective management of resources. Science, 302(5652), 1912-1914.

Pretty, J., \& Ward, H. (2001). Social capital and the environment. World development, 29(2), 209-227.

Putnam, R. D., Leonardi, R., \& Nanetti, R. Y. (1994). Making democracy work: Civic traditions in modern Italy. Princeton university press.

Rode, J., Gómez-Baggethun, E., \& Krause, T. (2015). Motivation crowding by economic incentives in conservation policy: A review of the empirical evidence. Ecological Economics, 117, 270-282.

R Core Team (2018). R: A language and environment for statistical computing. R Foundation for Statistical Computing, Vienna, Austria. URL https://www.R-project.org/.

Selman, P. (2001). Social capital, sustainability and environmental planning. Planning theory \& practice, 2(1), 13-30.

Shove, E. (2010). Beyond the ABC: climate change policy and theories of social change. Environment and planning A, 42(6), 1273-1285.

Shove, E. (2012). Habits and their creatures.

Southgate, D., \& Wunder, S. (2009). Paying for watershed services in Latin America: a review of current initiatives. Journal of Sustainable Forestry, 28(3-5), 497-524.

Spence, A., Poortinga, W., Butler, C., \& Pidgeon, N. F. (2011). Perceptions of climate change and willingness to save energy related to flood experience. Nature climate change, 1(1), 46.

Stedman, R. C. (2002). Toward a social psychology of place: Predicting behaviour from place-based cognitions, attitude, and identity. Environment and behaviour, 34(5), 561-581.

Stern, P. C. (2000). New environmental theories: toward a coherent theory of environmentally significant behaviour. Journal of social issues, 56(3), 407-424.

Terry, D. J., Hogg, M. A., \& White, K. M. (1999). The theory of planned behaviour: self-identity, social identity and group norms. British journal of social psychology, 38(3), 225-244.

Thøgersen, J. (2006). Norms for environmentally responsible behaviour: An extended taxonomy. Journal of environmental Psychology, 26(4), 247-261.

Van der Werff, E., Steg, L., \& Keizer, K. (2013). The value of environmental self-identity: The relationship between biospheric values, environmental self-identity and environmental preferences, intentions and behaviour. Journal of Environmental Psychology, 34, 55-63.

Van Hecken, G., \& Bastiaensen, J. (2010). Payments for ecosystem services in Nicaragua: do market-based approaches work?. Development and Change, 41(3), 421-444.

Vatn, A. (2010). An institutional analysis of payments for environmental services. Ecological economics, 69(6), 12451252.

Vedeld, P., Angelsen, A., Bojö, J., Sjaastad, E., \& Berg, G. K. (2007). Forest environmental incomes and the rural poor. Forest Policy and Economics, 9(7), 869-879.

Venables, W. N., \& Ripley, B. D. (2002). Modern applied statistics with S, Springer-Verlag. New York.

Wakefield, S. E., Elliott, S. J., Eyles, J. D., \& Cole, D. C. (2006). Taking environmental action: the role of local composition, context, and collective. Environmental Management, 37(1), 40-53. 
Wickham H. (2016). ggplot2: Elegant Graphics for Data Analysis. Springer-Verlag New York. ISBN 978-3-319-242774 ,

Woolcock, M., \& Narayan, D. (2000). Social capital: Implications for development theory, research, and policy. The world bank research observer, 15(2), 225-249.

Wunder, S. (2006). Are direct payments for environmental services spelling doom for sustainable forest management in the tropics?. Ecology and society, 11(2).

Wunder, S. (2008). Payments for environmental services and the poor: concepts and preliminary evidence. Environment and development economics, 13(3), 279-297.

Wunder, S. (2015). Revisiting the concept of payments for environmental services. Ecological Economics, 117, 234243.

Wunder, S., Angelsen, A., \& Belcher, B. (2014). Forests, livelihoods, and conservation: Broadening the empirical base. World Development, 64 (S1), pp. S1-S11.

Wunder, S., Engel, S., \& Pagiola, S. (2008). Taking stock: A comparative analysis of payments for environmental services programs in developed and developing countries. Ecological economics, 65(4), 834-852.

Zbinden, S., \& Lee, D. R. (2005). Paying for environmental services: an analysis of participation in Costa Rica's PSA program. World development, 33(2), 255-272. 


\section{Appendices and supplementary materials}

Appendix 1. Summary of Logistic model of the probability of participation in ARAs and the censored Tobit model for the area enrolled in ARAs. Variables that were not included in one of the model are indicated by "n.i." ("not included"). Estimates include community dummies for each community, that are displayed at the end of the table. The code for the $\mathbf{p}$-value is $\mathbf{p}<0.01(* * *)-\mathbf{p}<0.05(* *)-\mathbf{p}<0.1(*)-\mathbf{p}<0.15($.)

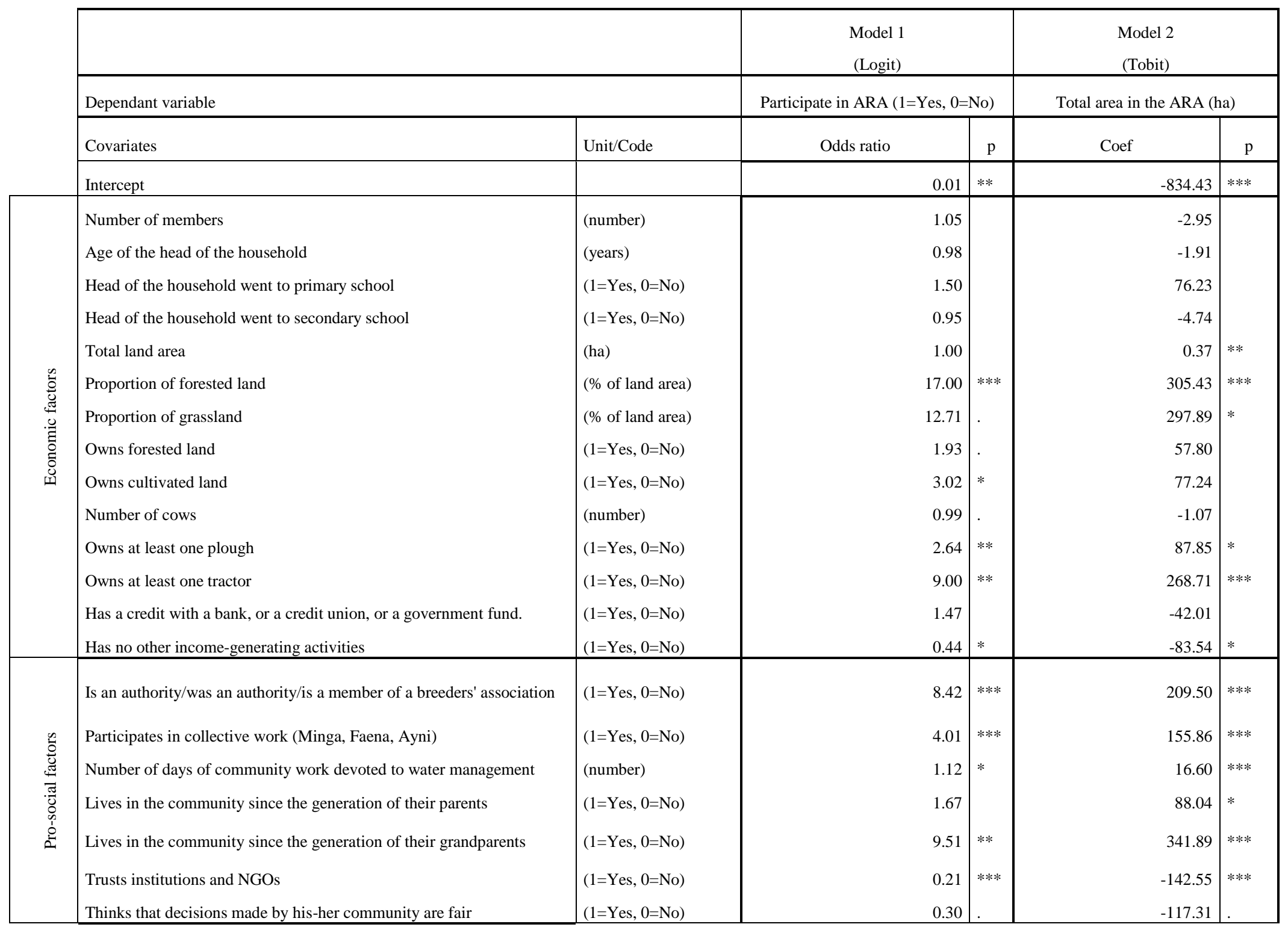




\begin{tabular}{|c|c|c|c|c|c|c|}
\hline 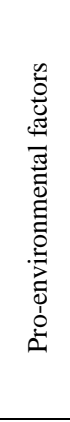 & $\begin{array}{l}\text { Knows how his-her community can protect the environment } \\
\text { Thinks that the forest provides fodder, non-timber forest products, } \\
\text { timber, firewood and bushmeat } \\
\text { Thinks that the forest brings rain, maintains water quality, maintains } \\
\text { water quantity, stabilizes the climate } \\
\text { Thinks that the forest brings a nice view } \\
\text { Environmental protection is an important value that he wants to teach } \\
\text { his-her children } \\
\text { Wants support for water and environmental management }\end{array}$ & $\begin{array}{l}(1=\text { Yes, } 0=\mathrm{No}) \\
(1=\text { Yes, } 0=\mathrm{No}) \\
(1=\text { Yes, } 0=\mathrm{No}) \\
(1=\text { Yes, } 0=\mathrm{No}) \\
(1=\text { Yes, } 0=\mathrm{No}) \\
(1=\text { Yes, } 0=\mathrm{No})\end{array}$ & $\begin{array}{l}2.19 \\
5.40 \\
0.39 \\
2.70 \\
\end{array}$ & $\begin{array}{l}* \\
* * \\
* \\
* \\
* * \\
* * \\
* *\end{array}$ & $\begin{array}{r}122.91 \\
\text { n.i. } \\
108.51 \\
\text { n.i. } \\
-67.51 \\
109.76 \\
\end{array}$ & $\begin{array}{l}* * \\
\text { n.i. }\end{array}$ \\
\hline 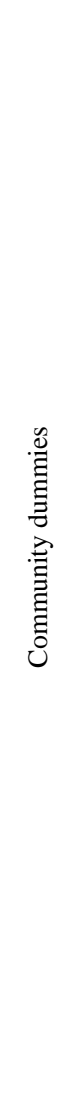 & $\begin{array}{l}\text { Community } 1 \\
\text { Community } 2 \\
\text { Community } 3 \\
\text { Community } 4 \\
\text { Community } 5 \\
\text { Community } 6 \\
\text { Community } 7 \\
\text { Community } 8 \\
\text { Community } 9 \\
\text { Community } 10 \\
\text { Community } 11 \\
\text { Community } 12 \\
\text { Community } 13 \\
\text { Community } 14 \\
\text { Community } 15 \\
\text { Community } 16 \\
\text { Community } 17 \\
\text { Community } 18 \\
\text { Community } 19 \\
\text { Community } 20 \\
\text { Community } 21 \\
\end{array}$ & $\begin{array}{l}(1=\text { Yes, } 0=\mathrm{No}) \\
(1=\text { Yes, } 0=\mathrm{No}) \\
(1=\text { Yes, } 0=\mathrm{No}) \\
(1=\text { Yes, } 0=\mathrm{No}) \\
(1=\text { Yes, } 0=\mathrm{No}) \\
(1=\text { Yes, } 0=\mathrm{No}) \\
(1=\text { Yes, } 0=\mathrm{No}) \\
(1=\text { Yes, } 0=\mathrm{No}) \\
(1=\text { Yes, } 0=\mathrm{No}) \\
(1=\text { Yes, } 0=\mathrm{No}) \\
(1=\text { Yes, } 0=\mathrm{No}) \\
(1=\text { Yes, } 0=\mathrm{No}) \\
(1=\text { Yes, } 0=\mathrm{No}) \\
(1=\text { Yes, } 0=\mathrm{No}) \\
(1=\text { Yes, } 0=\mathrm{No}) \\
(1=\text { Yes, } 0=\mathrm{No}) \\
(1=\text { Yes, } 0=\mathrm{No}) \\
(1=\text { Yes, } 0=\mathrm{No}) \\
(1=\text { Yes, } 0=\mathrm{No}) \\
(1=\text { Yes, } 0=\mathrm{No}) \\
(1=\text { Yes, } 0=\mathrm{No})\end{array}$ & $\begin{array}{r}0.46 \\
2.81 \\
0.22 \\
4.64 \\
0.14 \\
3.35 \\
0.35 \\
0.56 \\
1.82 \\
77.13 \\
1.46 \\
2.07 \\
0.78 \\
0.51 \\
1.09 \\
7.94 \\
0.85 \\
3.63 \\
0.78 \\
30.18 \\
14.11 \\
\end{array}$ & $\begin{array}{l}* * * \\
* * * \\
\end{array}$ & $\begin{array}{r}-71.24 \\
194.98 \\
-29.49 \\
172.30 \\
-124.96 \\
72.15 \\
-99.08 \\
4.92 \\
59.12 \\
697.87 \\
76.26 \\
41.54 \\
13.60 \\
52.88 \\
20.33 \\
171.47 \\
132.59 \\
229.19 \\
18.30 \\
416.38 \\
292.17 \\
\end{array}$ & $\begin{array}{l}* * * \\
* * \\
*\end{array}$ \\
\hline & & $\begin{array}{l}\text { AIC } \\
\text { Mc Fadden R2 } \\
\end{array}$ & $\begin{array}{c}325.29 \\
0.45 \\
\end{array}$ & & $\begin{array}{c}1225.01 \\
0.17 \\
\end{array}$ & \\
\hline
\end{tabular}

Sample size: 424 households including 74 that participated in ARAs 


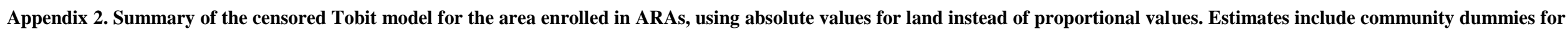
each community, but these are not displayed in this table in order to save space. The code for the p-value is p<0.01 $(* * *)-\mathbf{p}<0.05(* *)-p<0.1(*)-p<0.15($.

\begin{tabular}{|c|c|c|c|c|}
\hline & \multicolumn{2}{|l|}{ Type of statistical model } & \multicolumn{2}{|c|}{ Tobit } \\
\hline & Covariates & Unit/Code & Coef & $\mathrm{p}$ \\
\hline & Intercept & & -735.03 & $* * *$ \\
\hline 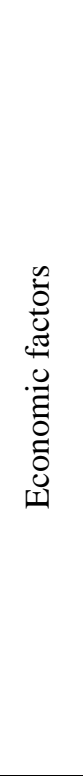 & $\begin{array}{l}\text { Number of members } \\
\text { Age of the head of the household } \\
\text { Head of the household went to primary school } \\
\text { Head of the household went to secondary school } \\
\text { Superficie of forested land } \\
\text { Superficie of grassland } \\
\text { Superficie of cultivated land } \\
\text { Owns forested land } \\
\text { Owns cultivated land } \\
\text { Number of cows } \\
\text { Owns at least one plough } \\
\text { Owns at least one tractor } \\
\text { Has a credit with a bank, or a credit union, or a government fund. } \\
\text { Has no other income-generating activities }\end{array}$ & $\begin{array}{l}(\text { number }) \\
(\text { years }) \\
(1=\text { Yes, } 0=\mathrm{No}) \\
(1=\text { Yes, } 0=\mathrm{No}) \\
(\text { ha) } \\
(\text { ha) } \\
(\text { ha) } \\
(1=\text { Yes, } 0=\mathrm{No}) \\
(1=\text { Yes, } 0=\mathrm{No}) \\
(\text { number }) \\
(1=\text { Yes, } 0=\mathrm{No}) \\
(1=\text { Yes, } 0=\mathrm{No}) \\
(1=\text { Yes, } 0=\mathrm{No}) \\
(1=\text { Yes, } 0=\mathrm{No})\end{array}$ & $\begin{array}{r}0.19 \\
-1.84 \\
109.76 \\
48.35 \\
0.63 \\
-1.26 \\
-5.37 \\
97.94 \\
144.45 \\
-0.13 \\
87.32 \\
257.83 \\
-23.18 \\
-106.48\end{array}$ & $\begin{array}{l}* * * \\
. \\
* * \\
* * \\
* \\
* * * \\
* *\end{array}$ \\
\hline 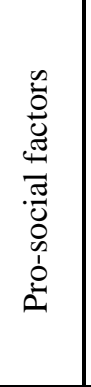 & $\begin{array}{l}\text { Is an authority/was an authority/is a member of a breeders' association } \\
\text { Participates in collective work (Minga, Faena, Ayni) } \\
\text { Number of days of community work devoted to water management } \\
\text { Lives in the community since the generation of their parents } \\
\text { Lives in the community since the generation of their grandparents } \\
\text { Trusts institutions and NGOs } \\
\text { Thinks that decisions made by his-her community are fair }\end{array}$ & $\begin{array}{l}(1=\text { Yes, } 0=\mathrm{No}) \\
(1=\text { Yes, } 0=\mathrm{No}) \\
(\text { number }) \\
(1=\text { Yes, } 0=\mathrm{No}) \\
(1=\text { Yes, } 0=\mathrm{No}) \\
(1=\text { Yes, } 0=\mathrm{No}) \\
(1=\text { Yes, } 0=\mathrm{No})\end{array}$ & $\begin{array}{r}208.93 \\
153.04 \\
14.72 \\
72.41 \\
324.93 \\
136.18 \\
-83.77\end{array}$ & $\begin{array}{l}* * * \\
* * * \\
* * \\
. \\
* * * \\
* * *\end{array}$ \\
\hline \multirow[t]{2}{*}{ 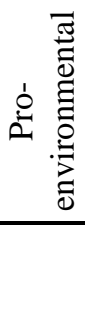 } & $\begin{array}{l}\text { Knows how his-her community can protect the environment } \\
\text { Thinks that the forest brings rain, maintains water quality, maintains water quantity, stabilizes the climate } \\
\text { Environmental protection is an important value that he wants to teach his-her children } \\
\text { Wants support for water and environmental management }\end{array}$ & $\begin{array}{l}(1=\text { Yes, } 0=\mathrm{No}) \\
(1=\text { Yes, } 0=\mathrm{No}) \\
(1=\text { Yes, } 0=\mathrm{No}) \\
(1=\text { Yes, } 0=\mathrm{No})\end{array}$ & $\begin{array}{r}133.25 \\
91.32 \\
-49.01 \\
96.89\end{array}$ & $\begin{array}{l}* \\
* * \\
* *\end{array}$ \\
\hline & & $\begin{array}{l}\text { AIC } \\
\text { Mc Fadden } \mathrm{R}^{2}\end{array}$ & \multicolumn{2}{|c|}{$\begin{array}{c}1233.84 \\
0.17\end{array}$} \\
\hline
\end{tabular}




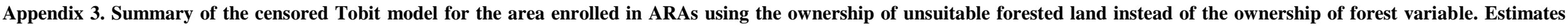

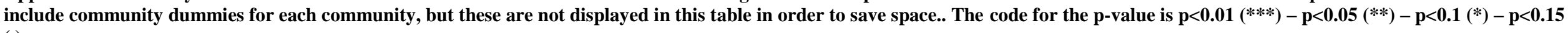
(.)

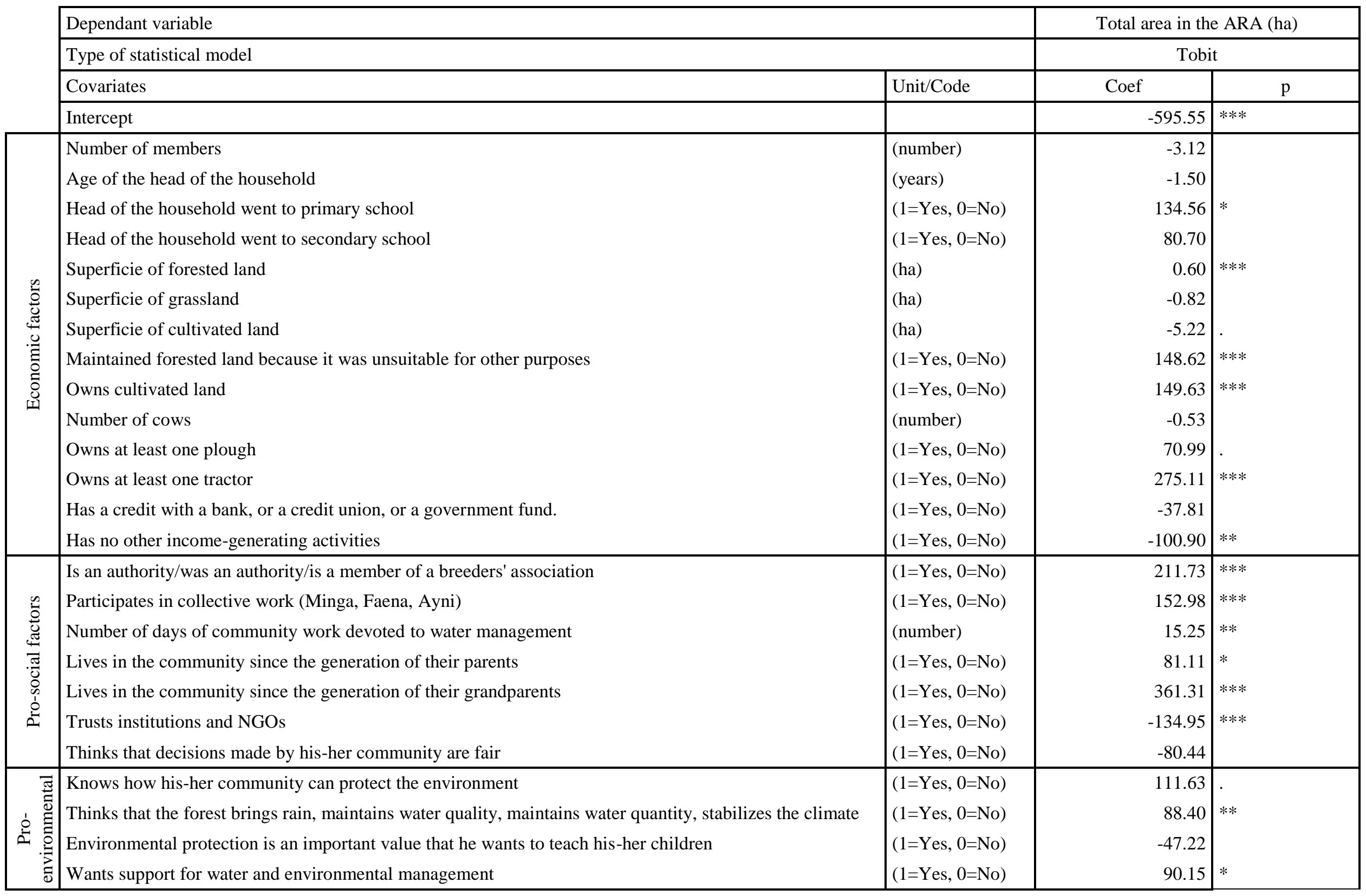


AIC

Sample size: 424 households including 74 that participated in ARAs
1216.95

0.18 


\section{Endnotes}

${ }^{1} \mathrm{~A}$ PES is a voluntary contractual transaction between suppliers of ES, playing a central role in the production or maintenance of these services and who incur its costs, and ES users (Wunder, 2015).

${ }^{2}$ Social norms are reflected in a shared, informal and implicit understanding of how to behave in regular social situations, encouraging people to act in ways that are compatible with the expectations of others (Fehr and Fischbacher, 2004; Thøgersen, 2006), because they may fear social sanctions if they violate social norms or because they may think that the most common behaviour is the most logical, efficient or appropriate one.

${ }^{3}$ Natura also argue that relying on other types of motivations is less costly because they don't have to pay the exact opportunity cost of conservation and they don't have to calculate it through long studies (Asquith, 2016). Indeed, compensation's monetary value per hectare is very low compared to usual PES programs. Nor they don't have to calculate the value of the services produced by upstream farmers' forests through supply and demand, which distances ARAs from market-based instruments for conservation.

${ }^{4}$ Actually, due to a lack of time and resources, Natura's relationships with communities seem to be quite scattered in the study area, as expressed by some of the beneficiaries and the public distribution of compensations is not always happening that way.

${ }^{5}$ However, these collective environmental education sessions are short (about 15 minutes) and only take place once (when the ARAs are offered).

${ }^{6}$ The significantly positive effect of the forest ownership variable is more salient in Appendix 1 model using the absolute areas of land instead of the relatives ones, because this variable is actually correlated to the proportion of forested land (Anova test eta $=0.216^{* * *}$ ) 


\section{CEE-M Working Papers 1 - 2020}

WP $2020-01$

Francisco Cabo \& Mabel Tidball

«Cooperation in a dynamic setting with asymmetric environmental valuation and responsibility»

WP $2020-02$

Mathias Berthod

"Commitment and efficiency-inducing tax and subsidy scheme in the development of a clean technology»

WP $2020-03$

Manon Authelet, Julie Subervie, Patrick Meyfroidt, Nigel Asquith \& Driss Ezzine-de-Blas

Economic, Pro-social and Pro-environmental Factors Influencing

Participation in an Incentive-based Conservation Program in Bolivia

${ }^{1}$ CEE-M Working Papers / Contact : laurent.garnier@inra.fr

- RePEc https://ideas.repec.org/s/hal/wpceem.html

- HAL https://halshs.archives-ouvertes.fr/CEE-M-WP/ 